
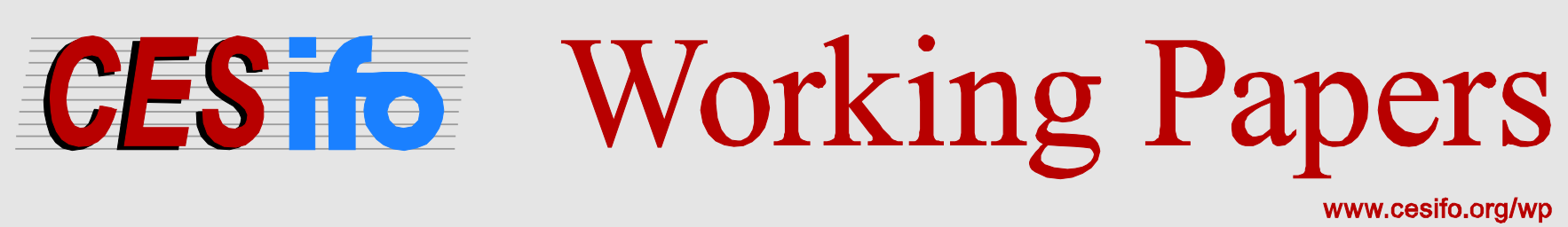

\title{
Iceland: How Could This Happen?
}

\author{
Thorvaldur Gylfason
}

\author{
CESIFO WORKING PAPER NO. 4605 \\ Category 6: Fiscal Policy, Macroeconomics and Growth \\ JANUARY 2014
}

An electronic version of the paper may be downloaded

- from the SSRN website:

- from the RePEc website:

- from the CESifo website:

www.SSRN.com

Www.RePEc.org

www.CESifo-group.org/wp

\section{CESifo}




\title{
Iceland: How Could This Happen?
}

\begin{abstract}
This paper reviews economic developments in Iceland following its financial collapse in 2008, focusing on causes and consequences of the crash. The review is presented in the context of the Nordic region, with broad comparisons also with developments elsewhere on the periphery of Europe, in Greece, Ireland, and Portugal. In some ways, however, Iceland resembles Italy, Japan, and Russia more than it resembles its Nordic neighbors or even Ireland. The paper also considers the uncertain prospects for reforms and restoration as well as the possible effects of the crash on social, human, and real capital and on long-run economic growth.
\end{abstract}

JEL-Code: G010, O400.

Keywords: Iceland, financial crisis, social capital.

Thorvaldur Gylfason

Department of Economics

University of Iceland

Iceland-101 Reykjavík

gylfason@hi.is 


\title{
Iceland: How Could This Happen?
}

\author{
Thorvaldur Gylfason ${ }^{1}$ \\ "The Chamber of Commerce recommends that Iceland stop comparing itself \\ with other Nordic countries because we are superior to them in most respects." \\ Iceland Chamber of Commerce, February 2008. ${ }^{2}$
}

This chapter reviews recent economic developments in Iceland following its financial collapse in 2008 , focusing on causes and consequences of the crash. The review is presented in the context of the Nordic region, with broad comparisons also with developments elsewhere on the periphery of Europe, in Greece, Ireland, and Portugal, all small countries. In telling my story, I will need to look beyond economics in a narrow sense of the term because Iceland's troubles are as much political as economic. Think of it this way: you would not undertake to analyze, for example, Ukrainian events by econometrics alone, or by IS-LM curves, because you need a bit more: you need historical and political context, among other things. In some ways, as you will see, Iceland resembles Italy, Japan, and Russia more than it resembles its Nordic neighbors or even Ireland. ${ }^{3}$ Iceland has taken a path in economic, political, and social affairs that is in some ways quite different from that of its Nordic neighbors, with results that

\footnotetext{
${ }^{1}$ Professor of Economics, University of Iceland. This chapter is a revised, written version of my presentation at a conference on Reform Capacity and Macroeconomic Performance in the Nordic Countries held at the Copenhagen Business School in Copenhagen, Denmark, 20-21 September 2013. I am grateful to my discussant, Søren Bo Nielsen, as well as to other conference participants and several other readers at home and abroad for their reactions to my earlier version of the story. The chapter will appear in a book entitled Reform Capacity and Macroeconomic Performance in the Nordic Countries edited by Torben M. Andersen, Michael Bergman, and Svend E. Hougaard Jensen, published by Oxford University Press.

${ }^{2}$ Undeterred by events, the Iceland Chamber of Commerce continues to dispense its advice. In mid-2013, the Icelandic government proposed a new law that would make it illegal not to consult the Iceland Chamber of Commerce, the Confederation of Icelandic Employers, the Icelandic Confederation of Labor, and the Association of Local Authorities concerning legislation and administrative decisions of interest to them. ${ }^{3}$ Anthropological research suggests that about two thirds of the Viking settlers of Iceland from the $9^{\text {th }}$ century onward came from Norway while the remaining third arrived from Ireland.
} 
have proved correspondingly different.

This chapter surveys Iceland's economic landscape five years after the crash of 2008 by providing broad historical cross-country macroeconomic comparisons with an emphasis on failed banks and broken trust. It also considers the uncertain prospects for reforms and restoration. As a brief bonus toward the end I stress the striking resemblance between developments in Iceland and those in its closest neighbor, the Faroe Islands, a self-governing country of 50,000 people within the Danish Realm since 1948. I also suggest directions for further research on the possible effects of Iceland's financial crash in 2008 on social, human, and real capital and thereby ultimately on long-run economic growth.

\section{Background}

In 1904 when Iceland was granted long wished-for home rule by Denmark, the opportunity emerged from a new liberal government in Denmark (systemskiftet 1901). For 30 years, or 55 years, depending on how you count, ${ }^{4}$ Icelandic politicians had sought increased sovereignty. This was in vain, due to divisive internal squabbling as well as to firm opposition by the Danish king. At the time, around 1900, Iceland's per capita gross national income was about half that of Denmark's. In today's money, that was roughly equivalent to Ghana's current per capita GNI at purchasing power parity. Over the next few decades, Iceland caught up with Denmark, reaching parity with today's India in 1930, China in 1960, and Korea in $2008 .{ }^{5}$ The approximate parity with Denmark and the rest of the Nordic countries in terms of per capita GNI from at least 1980 onward (ppp-adjusted estimates of national income do not reach farther back) was abruptly severed by the crash of 2008 (Figure 1).

\footnotetext{
${ }^{4}$ One may start counting in 1874 when the Icelanders celebrated the $1000^{\text {th }}$ anniversary of the country s settlement and Christian IX King of Denmark handed the Icelanders their first constitution, essentially a copy of the Danish one, or in 1851 when, in the wake of Denmark's National Assembly of 1849, Iceland's National Assembly was, in the spirit of the times, unilaterally dissolved by the local representative of the Danish king. The National Assembly of 1851 was not a complete fiasco, however, because it laid the basis for the elimination of the last vestiges of the Danish trade monopoly in Iceland in 1855.

${ }^{5}$ These comparisons are updated versions of those presented in Gylfason (2008).
} 
Figure 1. GNI per capita 1980-2012 (Current international \$, ppp) ${ }^{6}$

Nordics

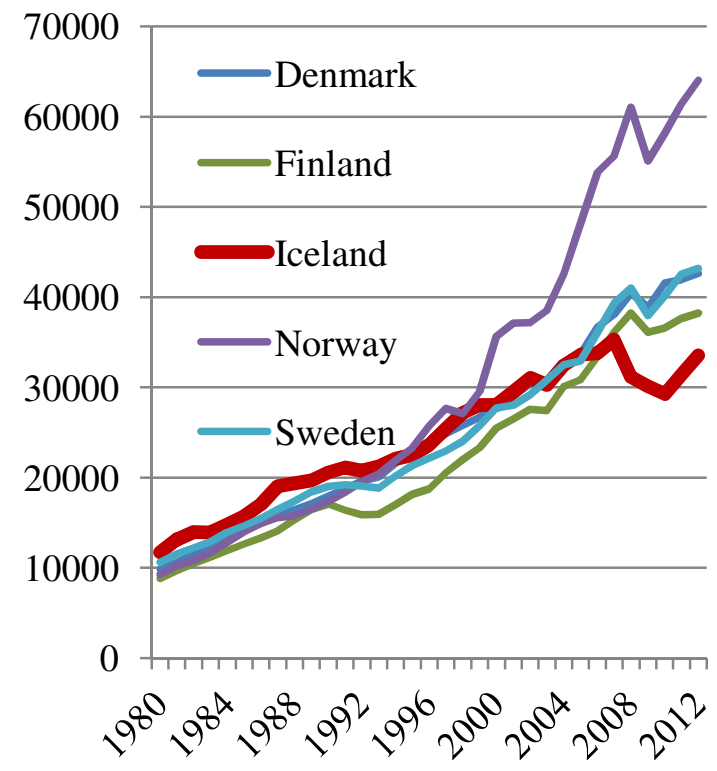

Periphery

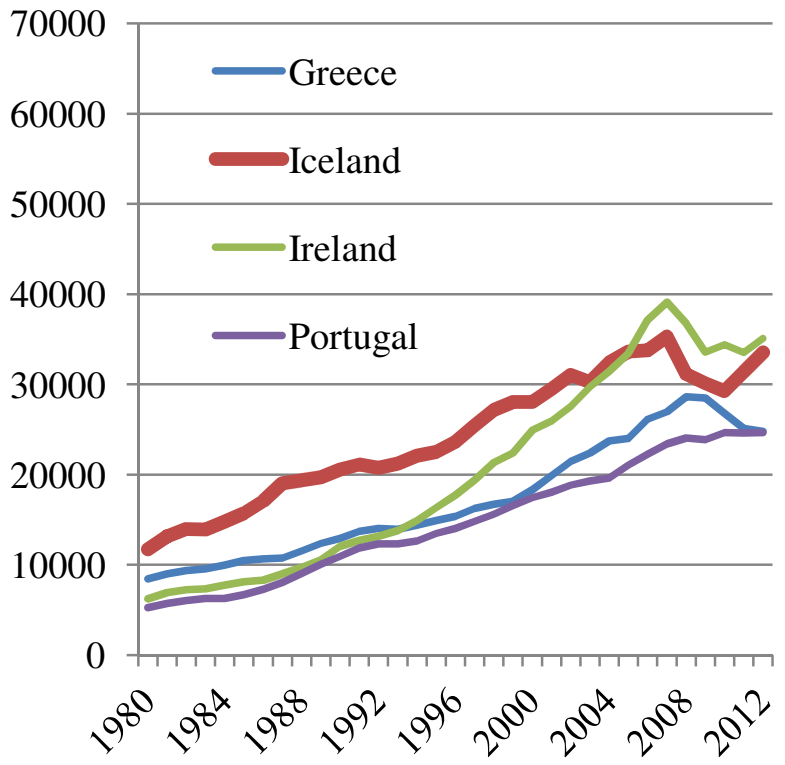

Figure 1 highlights several points.

First, Norway parted company with the rest of the Nordics in terms of per capita GNI before 2000, aided by its judiciously managed oil wealth, and remains in a class its own. The figure actually understates Norway's surge ahead of the rest of the pack because the Norwegians have cashed out on their economic success through fewer hours of work as well as higher incomes (Figure 2). By showing hours of work per employee rather than per capita, Figure 2 makes too little of the difference between Iceland and the rest because Iceland's labor force participation rate of about 75 percent since 1990 is far higher than in the rest of the Nordics (61 to 66 percent on average) as well as in the periphery (52 to 61 percent). Figure 3 shows hours of work per capita obtained by multiplying hours of work per employee by the participation rate. Figure 4 shows that, in terms of GNI per hour worked, Iceland started long before the crash to lag behind its neighbors for various well-known reasons of inefficiency to be addressed below.

\footnotetext{
${ }^{6}$ The source behind the figures throughout the chapter is the World Bank's World Development Indicators unless otherwise indicated.
} 
Figure 2. Hours of work per employee 1950-2012

Nordics

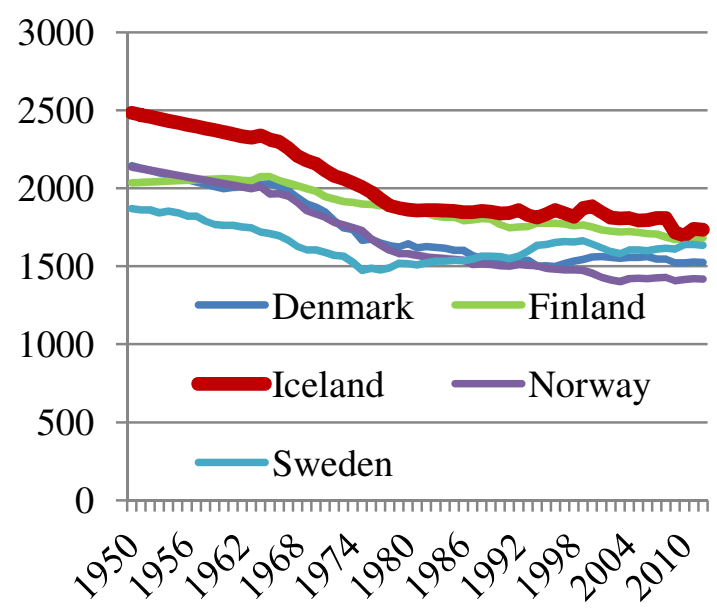

Periphery

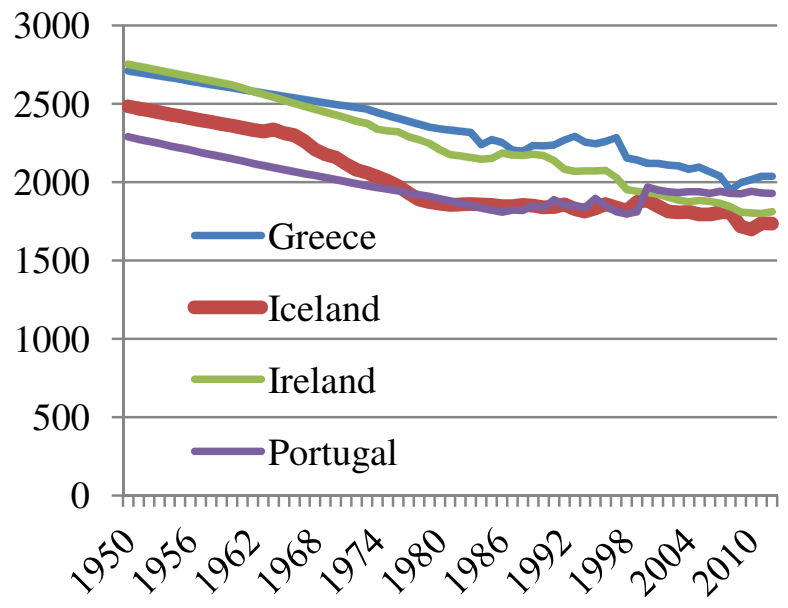

Figure 3. Hours of work per capita 1950-2012

Nordics

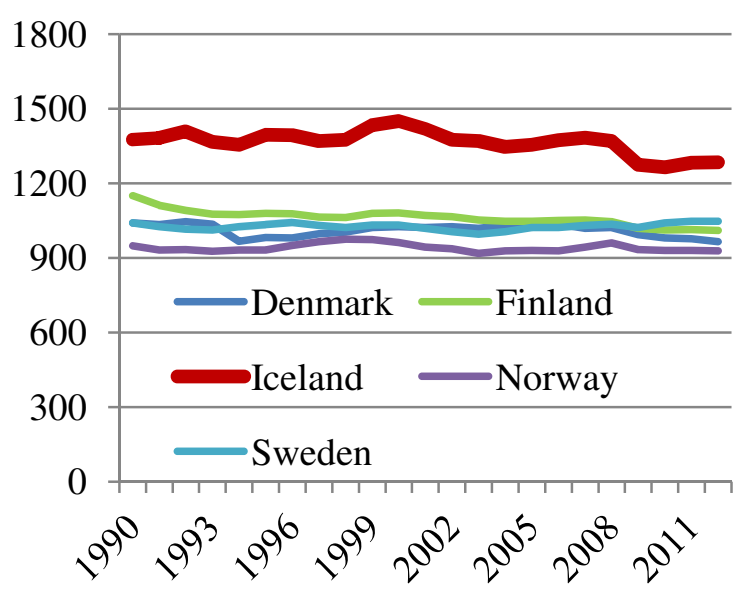

Periphery

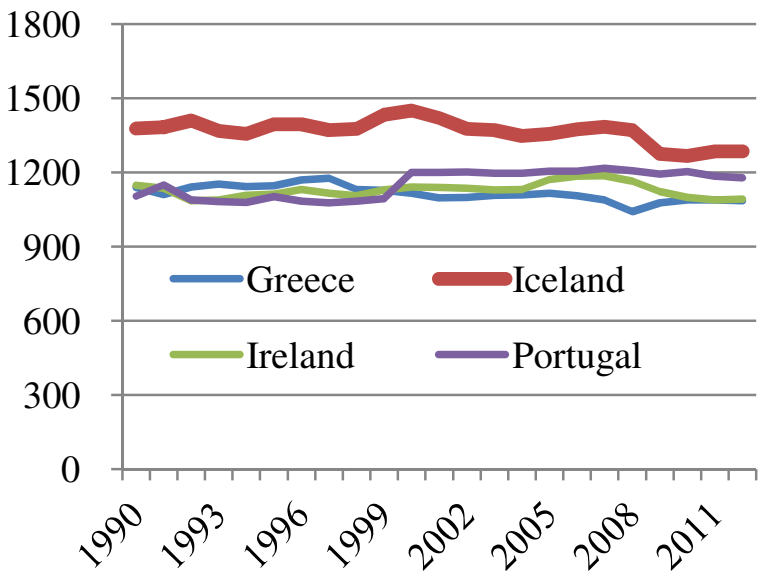

Second, Ireland parted company with Greece and Portugal after 1990 and bypassed Iceland some ten years later. One difference between the economic surges of Norway and Ireland is that Norway only experienced relatively minor effects of the Great Recession triggered by the collapse of Lehman Brothers in $2008^{9}$ while Ireland, like Iceland, suffered grave consequences, mostly of its own making (O'Toole, 2009). Figure 1 shows that Iceland's precrash boom does not stand out from trend in the way that Ireland's does. This suggests that the crash may have brought Iceland down to a lower but not necessarily flatter growth

\footnotetext{
${ }^{7}$ Source: The Conference Board Total Economy Database ${ }^{\mathrm{TM}}$, January 2013, http://www.conferenceboard.org/data/economydatabase/

${ }^{8}$ Source: Author's computations based on source given in footnote 7 as well as the World Bank's World Development Indicators.

${ }^{9}$ For an excellent account of the US financial crisis, see Blinder (2013).
} 
trajectory while Ireland may return to its pre-1995 trajectory. As in Iceland, per capita GNI in Ireland fell by 10 percent after 2008, compared with 20 percent in Latvia, an extreme case (not shown). Even so, joblessness rose far higher in Ireland than in Iceland and higher still in Greece (Figure 5).

Figure 4. GNI per hour worked 1990-2012 (Current international \$, ppp) ${ }^{10}$

Nordics

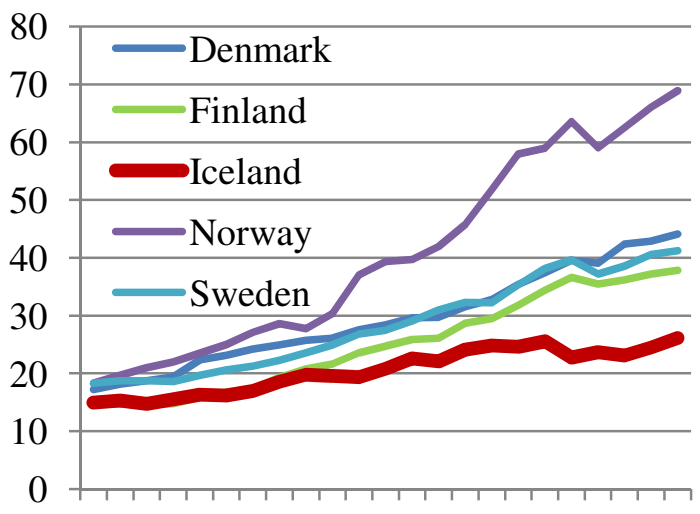

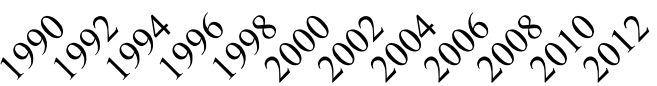

Periphery

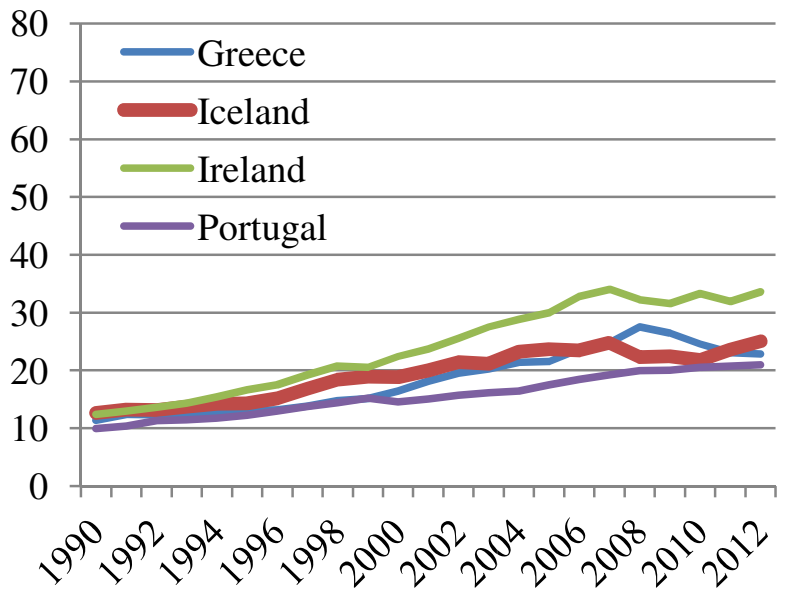

Figure 5. Unemployment 1980-2011 (\% of labor force)

Nordics

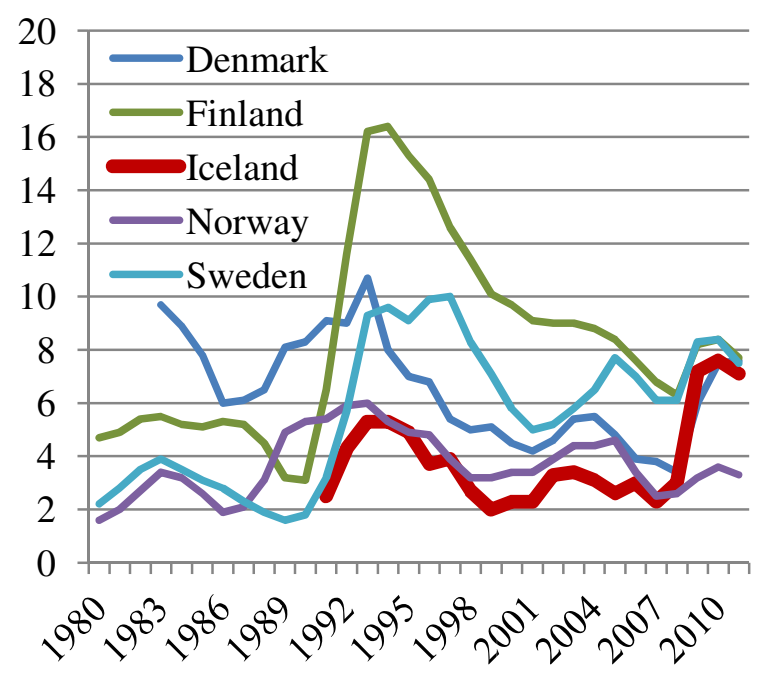

Periphery

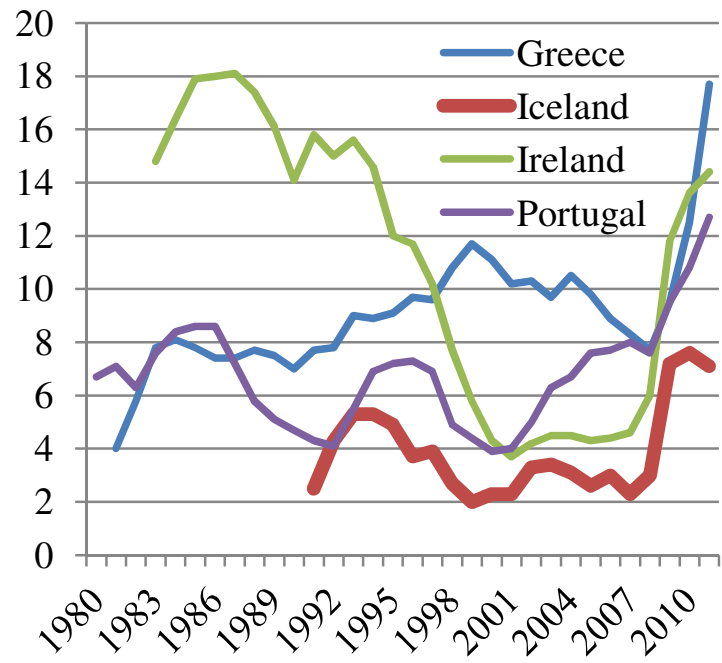

Third, in terms of the purchasing power of per capita GNI, Iceland parted company with the rest of the Nordics with the crash of 2008. The prospects for a return to the rest of the Nordic group are uncertain for reasons to be discussed in what follows. Figure 1 contradicts claims

\footnotetext{
${ }^{10}$ Source: Author's computations based on data presented in Figs. 1 and 3.
} 
that Iceland as well as Ireland and Greece were innocent victims of a worldwide downswing.

If they were innocent bystanders, the rest of the Nordics would have been similarly afflicted, but they were not.

In terms of income distribution, Iceland parted company with the Nordics as witnessed by the steady and unprecedented increase in economic inequality in Iceland during the 15 years preceding the crash (Gylfason et al., 2010, 155-156; Ólafsson and Kristjánsson, 2013). Iceland's experience echoes that of the Roaring Twenties in the United States where widening disparities in the distribution of income and wealth preceded - some would say, paved the way to - the Great Crash of 1929 (Galbraith, 1988, pp. 177-8; see also Galbraith, 2012). Equality increased again after the crash under the rescue package supported by the IMF. In terms of inflation, Iceland long ago parted company with the rest of the Nordics (Figure 6). Since 1939, the Icelandic króna has lost 95.95 percent of its value against the Danish krone. Iceland's inflation record is a long story of mismanagement, consistently evidenced by the OECD region's second highest inflation rate after Turkey. The problem persists: from 2005 to 2012, prices in Iceland rose by 58 percent compared with 17 percent in Denmark. Since 2005 the Central Bank has only once - briefly, in 2011 - met its inflation target of 2.5 percent. To assess the effectiveness of Iceland's monetary policy it is not enough, however, to know the Central Bank's Taylor rule and such; you also need to know that (a) in 2008 the Central Bank, having accepted worthless collateral, became technically bankrupt and needed to be bailed out at a cost equivalent to18 percent of $\mathrm{GDP}^{11}$ and (b) the (post-crash) governor sued the bank in a salary dispute, ${ }^{12}$ thus undermining the bank's pleas for general wage restraint.

\footnotetext{
${ }^{11}$ In 2012, senior Central Bank officials testified in the Court of Impeachment hearing of the criminal case brought by Parliament against Iceland's pre-crash Prime Minister, Geir Haarde, that the writing was on the wall already in 2006. On the stand, one senior Central Bank official likened the operations of the Icelandic banks before the crash to the Ponzi scheme operated by Bernard Madoff in the US. Even so, the Central Bank continued to lend money to the banks without adequate collateral, bankrupting itself in the process. The fiscal cost of recapitalizing the three commercial banks amounted to another 18\% of GDP (source: IMF).

12 The governor lost his case in a lower court as well as in the Supreme Court.
} 
Figure 6. Inflation 1961-2012 (Consumer prices, \% per year)

Nordics

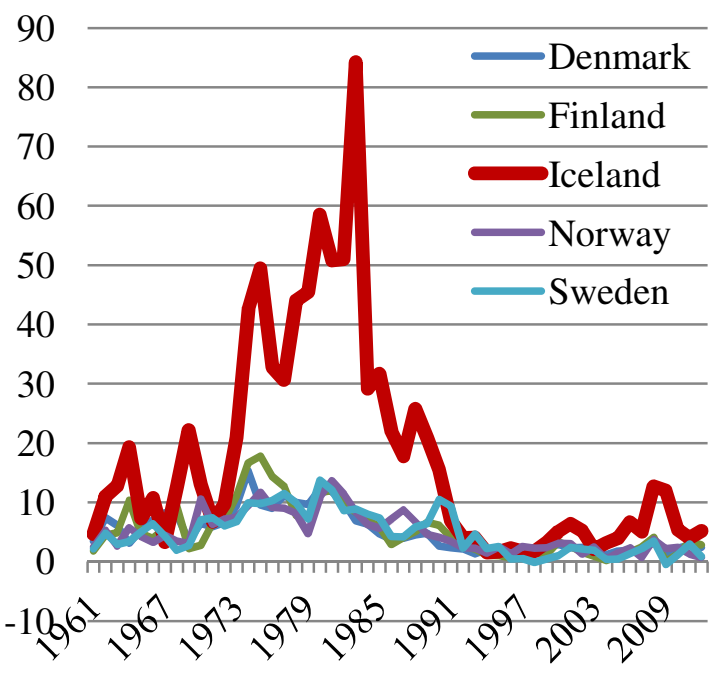

Periphery

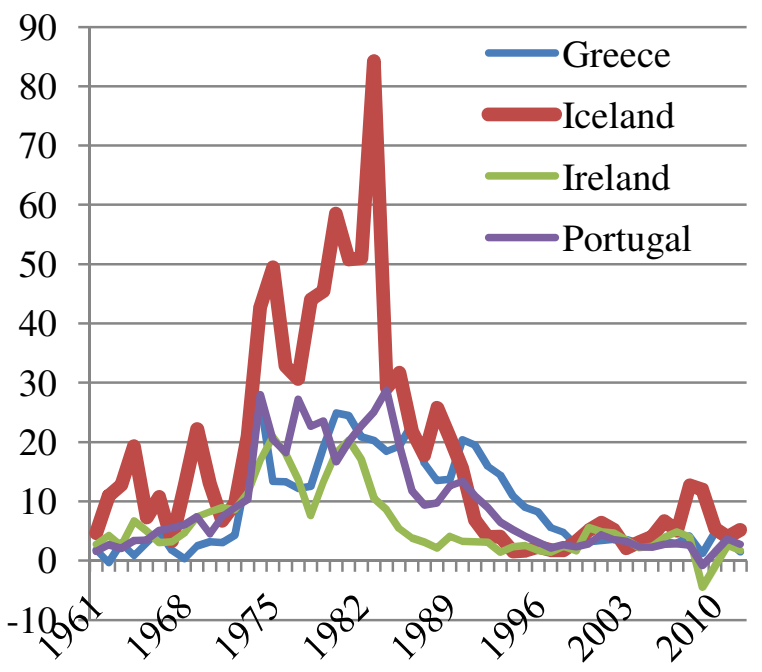

The next section briefly discusses the collapse of 2008, then looks at some key determinants of long-run economic performance spelling out Iceland's weak economic position vis-à-vis the rest of the Nordics (recall Figures 1 and 4). The crash and Iceland's less than stellar fundamentals may have a common origin in Iceland's political culture. Up against the wall, Parliament resolved unanimously in 2010 that (you may have to read this twice): "criticism of Iceland's political culture must be taken seriously and [Parliament] stresses the need for lessons to be learned from it. Parliament resolves that the report of the Special Investigation Commission of the Parliament constitutes a condemnation of the government, politicians, and public administration.” [My translation.]

\section{The banks}

One reason why Finland, Norway, and Sweden avoided major fallout from the Great Recession starting in 2008 is that they had learned their lesson from their own financial crises of 1988-1993 (Denmark escaped unscathed). At that time Finland, Norway, and Sweden were hit by serious bank failures following significant liberalization of the financial system without a commensurate strengthening of financial supervision (Jonung, Kiander, and Vartia, 2009). 
After that crash when unemployment in Finland, exacerbated by the collapse of trade with the former Soviet Union, increased to 16 percent of the labor force in 1993-1994, Finland, Norway, and Sweden beefed up their banking systems through private as well as public recapitalization and reorganization in a bipartisan spirit of transparency and openness (Honkapohja, 2009).

At the time of the Nordic banking crisis of 1988-1993 Iceland's state banks wrote off loans on an even larger scale relative to GDP than did the banks in the crisis-struck neighboring countries whose write-offs, in turn, exceeded those triggered by the Savings and Loans scandal of the 1980s and 1990s in the United States (Gylfason, 1995, Ch. 9). ${ }^{13}$ Even so, the Icelandic authorities did not acknowledge that there was a local financial crisis in the early 1990s. They did not have to do so because the banks faced no foreign competition so they could get back on an even keel simply by increasing the interest rate spread far beyond Nordic norms (more on this below).

Having thus got away with a cover-up, the Icelandic government was in no hurry to privatize its dysfunctional banking system even as the banks in East and Central Europe were being privatized in rapid succession after the collapse of communism in 1989-1991, many quite successfully. Estonia, for example, sold virtually all its bank assets to foreign owners.

With their ability to ration loans and foreign exchange, the state banks in Iceland were an essential part of the political power structure. The Icelandic crash of 2008, when in a matter of days the entire banking system collapsed, followed a similar pattern as the Nordic crises 20 years before. The pattern was liberalization without appropriate supervision but, in Iceland, preceded by Russian-style privatization. Two of the three state banks were sold at once at modest prices to well-connected locals rather than to experienced foreign bank owners as was

\footnotetext{
${ }^{13}$ From 1987 to 1993 , the Icelandic banks and other financial institutions wrote off loans equivalent to $11 \%$ of GDP in 1993. Original sources (in Icelandic) are given in Gylfason (1995, Ch. 9).
} 
done, for instance, in the Baltic countries lacking local financial expertise. Plans to sell the largest bank (Landsbanki) to Skandinaviska Enskilda Banken were suddenly shelved in favor of an Icelandic father-and-son team with business experience from St. Petersburg, Russia.

Figure 7. Bank assets 1990-2011 (\% of GDP)

Nordics

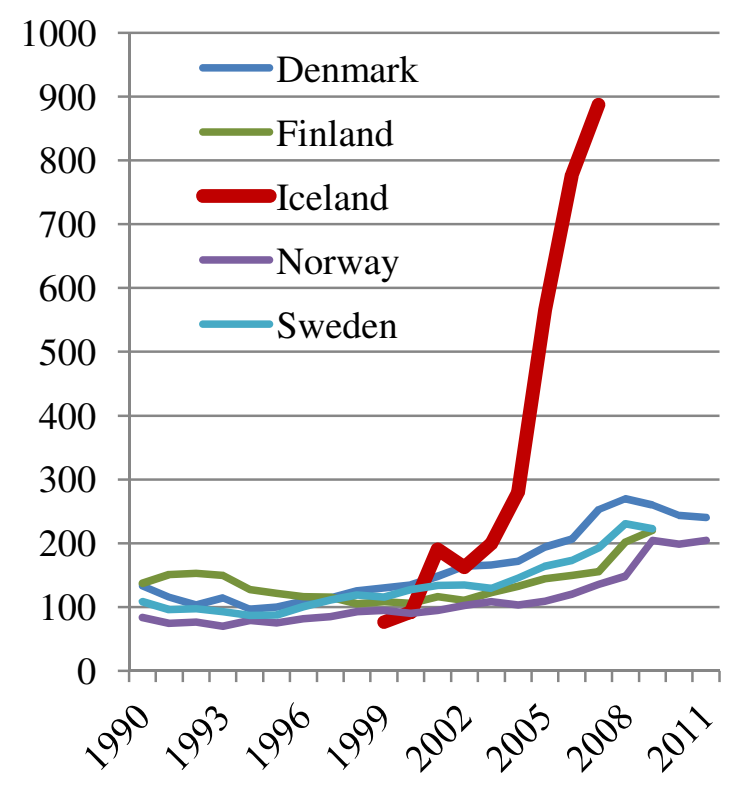

Periphery

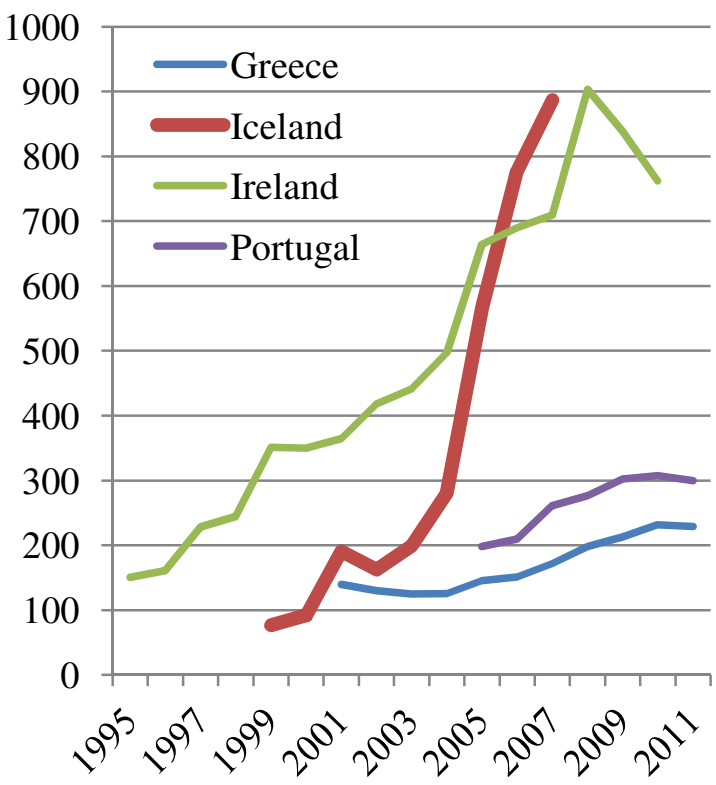

Under new private owners that found Iceland too small and unexciting, the three large

Icelandic banks (Glitnir, Landsbanki, and Kaupthing) decided to become international banks.

Within a few years, they outgrew by far the ability of the government to stand behind them as lenders, or rather borrowers, of last resort. ${ }^{14}$ What were the new owners thinking? By their own account, they grew to grow (Figure 7). The result was the abrupt bankruptcy of all three banks, surpassed in dollar terms only by the bankruptcy of Lehman Brothers and Washington Mutual in the United States (Gylfason, 2012, Fig. 1), including the personal bankruptcy of the main owner of Landsbanki (\$750 million, two thirds of which was owed to Landsbanki). This was apparently the biggest personal bankruptcy on record anywhere, including Texas.

How did the Icelandic banks manage to sink so fast and so deep? The answer lies not least in

\footnotetext{
${ }^{14}$ See Matthíasson (2008), Wade (2009), Gylfason et al. (2010), Benediktsdóttir, Daníelsson, and Zoega (2011), Wade and Sigurgeirsdóttir (2012), and Níelsson and Torfason (2012). For a collection of writings on events in Iceland before the crash, including a couple of pieces claiming all was well, see Aliber and Zoega (2011). For more on the two pieces in question, see Ferguson (2012, Ch. 8).
} 
the corrupt manner of their privatization, which at long last under pressure from the public Parliament in 2013 decided to have investigated without, however, appointing an investigation committee. ${ }^{15}$ As a result, there is as yet no sign of a pending investigation. Another contributing factor was the ineffectiveness of financial supervision which is best described as having been designed to fail. The 2,400-page report of the Special Investigation Commission (2010, vol. 2, p. 313) appointed by Parliament states clearly that the banks violated the law. Further, the SIC concluded that three Central Bank governors as well as the director of the Financial Supervision Authority plus three former ministers "showed neglect" in the exercise of their duties. Among all the bankers and politicians interviewed by the SIC, none expressed regret or accepted any responsibility for what happened. General amnesty appears unlikely. Forgiveness presupposes remorse, or at least an apology. Reconciliation requires truth. To heal, wounds must first be cleaned, as every doctor knows.

Under a new, apolitical, competent, and, as it turned out, temporary post-crash management, the FSA referred some 80 cases of suspected violations of the law to the Special Prosecutor, involving over 200 individuals suspected of insider trading, market manipulation, breach of fiduciary trust, and false accounting. At the end of 2012, the CEO of Glitnir was sentenced to nine months in prison. A year later, the CEO and Chairman of Kaupthing were sentenced to five and a half years and five years in prison, respectively. In 2013, the CEOs of two smaller banks, Byr and MP banki, and the Chairman of the latter got from one to four and a half years for breach of trust. Several mid-level managers and accomplices have also been handed prison sentences. During 2014, further cases involving Landsbanki among others are scheduled to be heard in court.

\footnotetext{
${ }^{15}$ Iceland's apparently tailor-made Law on financial institutions from 2002, article 52, states: "Directors and managers must ... have an unblemished reputation, and must not in the last five years have been declared bankrupt. They must not ... have been convicted over the past 10 years of a criminal offense under the Penal Code, ..." [My translation, italics added]. This piece of legislation set the tone for things to come. The National Audit Office (2013) highlights various features of the banks' privatization that lowered their purchase price.
} 
In all this, Iceland is by no means unique. The Savings and Loans crisis in California and Texas 20 years ago landed more than a thousand senior bankers in jail. Mel Brooks, the film director, may be said to have provided the script, adapted from his Oscar-winning 1968 movie The Producers in which an over-the-hill Hollywood producer is convinced by his hapless accountant that a flop pays better than a hit (Gylfason, 2010). Following Brooks, Black (1995) enumerates the four main ingredients of bank fraud: Extreme growth, making bad loans at a premium yield, extreme leverage, and grossly inadequate loss reserves. ${ }^{16}$

Unsurprisingly, Iceland's FSA had a bumpy ride. After repeated attempts by forces close to some of those under investigation to unseat the crime-busting post-crash director of the FSA, Mr. Gunnar Andersen, they succeeded in 2012, but by that time the most important cases were already in the hands of the Special Prosecutor who remains in office but whose budget allocation for 2014 was cut in half by a new government comprising the parties that privatized the banks in 1998-2003, paving the way to the cliff in 2008. In government circles, there are those who refer to the crash as the "so-called crash" as if nothing had happened. ${ }^{17}$

But things did happen. For one thing, Iceland's gross government debt rose by two thirds of GDP (Figure 8), making interest payments a huge public expenditure item absorbing five percent of GDP each year at least until 2018, crowding out essential expenditures to the point where Iceland's main hospital faces a life-threatening financial emergency. Of 147 banking crises since 1970, Iceland's crisis was the seventh costliest in terms of increased public debt and the third costliest in fiscal terms (Laeven and Valencia, 2012) ${ }^{18}$. Local residents lost savings equivalent to two times GDP. Foreign creditors, share holders, and depositors

\footnotetext{
${ }^{16}$ Are these isolated cases? No, says Black, quoting, among other sources, the US Treasury's Office of Comptroller of the Currency as saying: "The FBI estimates that 80 percent of all mortgage fraud involves collaboration or collusion by industry insiders." See also Akerlof and Romer (1993) and Stiglitz (2010, Ch. 5).

17 "There were older people who didn't even realize there had been a crisis," former Prime Minister Geir Haarde told The Guardian 6 October 2013.

${ }^{18}$ For comparison, Ireland's crisis was the sixth costliest in terms of increased public debt and the seventh costliest in fiscal terms.
} 
incurred losses equivalent to five times Iceland's annual GDP. Prices shot up as the króna lost half its value in nominal terms and a third of its value in real terms.

\section{Figure 8. General government gross debt 2001-2012 (\% of GDP) ${ }^{19}$}
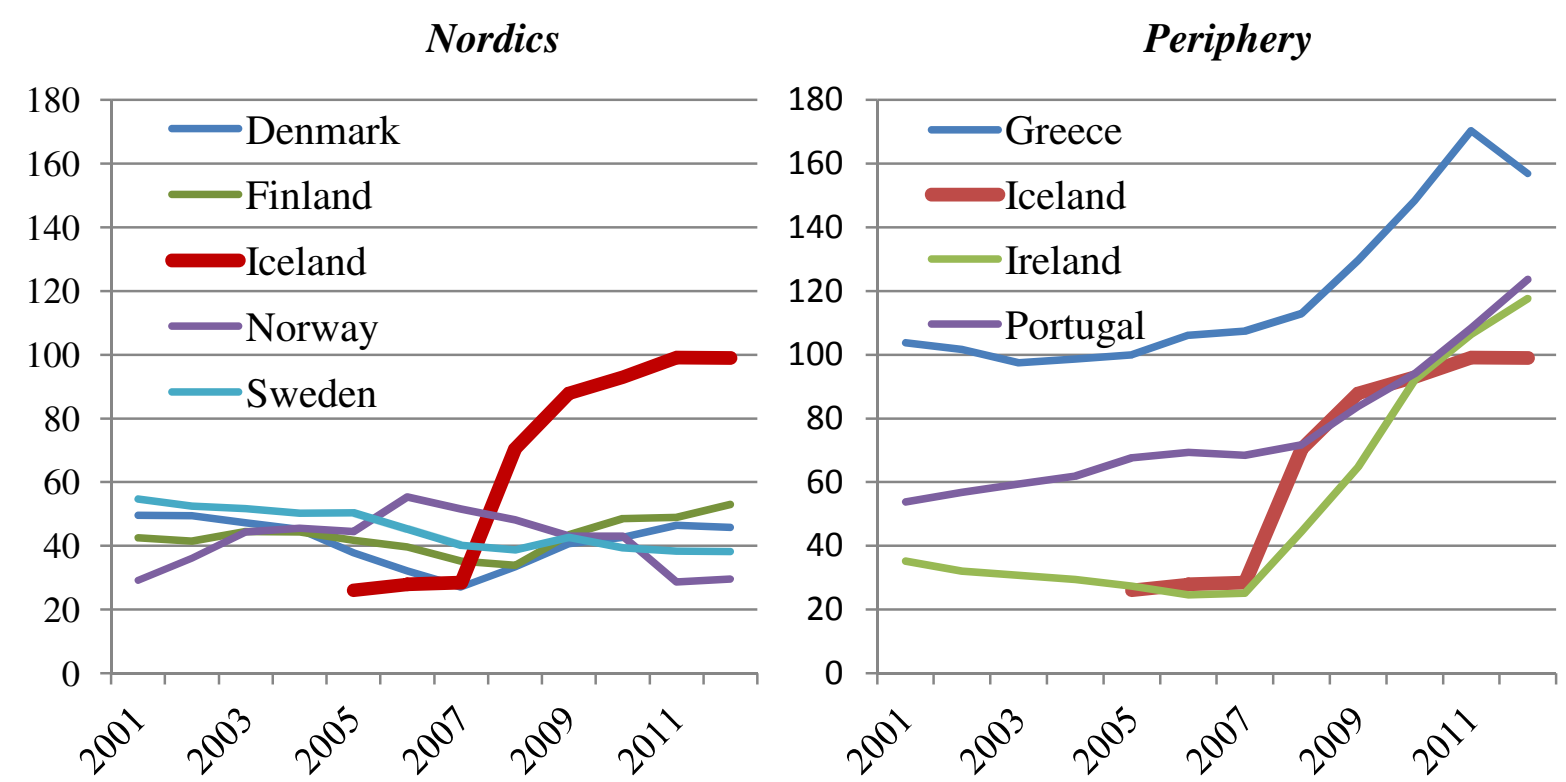

Unable to service their suddenly much larger mortgages, three families saw their homes repossessed every day on average during from 2009 to early 2013 by banks that continue in some ways to behave like a state within the state despite having been found guilty in court of legal violations, including the extension of foreign-currency denominated loans ruled illegal by the Supreme Court. ${ }^{20}$ A few years before the crash (2001), a Central Bank governor sat on the committee that drafted the legislation outlawing indexation to foreign currencies explicitly to protect unsuspecting domestic borrowers against predatory bank practices, but even so the Central Bank sat by idly as the banks extended such loans in large numbers. Thousands of gullible bank customers converted their high-interest local-currency loans indexed to domestic prices to low-interest loans indexed to foreign currencies only to see their loan principals double in local currency as the króna collapsed. Further, by its own admission, the Central Bank reduced reserve requirements to comply with the banks' wishes rather than try

\footnotetext{
${ }^{19}$ Source: Eurostat. Government debt is defined as consolidated general government gross debt of the whole general government sector

${ }^{20}$ Source: visir.is, 4 April 2013. Comparable figures on repossessions before the crash are not available.
} 
to restrain their growth to safeguard financial stability. ${ }^{21}$

Five years after the crash many borrowers remain unsure of the real value of their outstanding debts to the banks because the banks have been in no hurry to compensate their customers by writing down their loans, even after the Supreme Court has ruled the loans illegal. Individual borrowers have had to sue the banks in an attempt to induce them to comply with Supreme Court rulings. Further court cases involving controversial bank practices before and after the crash are pending.

In retrospect, the Icelandic banking sector was poorly prepared for liberalization, having been privatized as late as $1998-2003$. For more than a hundred years the banking system had comprised inept state bank institutions run by political operatives allocating subsidized credits and scarce foreign exchange to favored customers, paying scant attention to commercial profitability, risk, and economic health. In the 1990s, while dysfunctional banks in East and Central Europe were being transferred to new, often foreign, owners, Icelandic politicians could no longer resist demands for privatization, so they sold the banks - not to experienced foreign bank owners as initially envisaged but rather, at modest prices, to well-connected local parties entrusted to preserve the age-old umbilical cord binding politicians to the banks.

The new bank owners reciprocated the politicians' generosity. According to the Special Investigation Commission (2010, vol. 2, pp. 200-201, and vol. 8, pp. 164-170), the banks and related firms gave huge sums to political parties and politicians, equivalent to $\$ 8$ per person in Iceland in 2006. Further, the SIC reports that ten Members of Parliament out of 63 each owed the banks one million euro or more when the banks collapsed. The personal debts of the ten MPs averaged $€ 9$ million. The ten MPs include the leader of the Independence Party (now Finance Minister), his former deputy (now Director of the Board of the Central Bank), and

\footnotetext{
${ }^{21}$ The Vice Governor of the Central Bank, still in office, made the admission at a public meeting at the University of Iceland in June 2008, three months before the crash.
} 
five other party comrades. ${ }^{22}$ It is not known if these loans have been, or will be, settled. With many friends in political circles, the banks must have felt, and seemed to behave, like a state within the state, a sentiment seemingly exacerbated by unfettered cross-border banking and regulators and rating agencies looking the other way.

The three failed Icelandic banks, active in foreign markets, never faced foreign competition in the domestic market. Ireland's banking system, by comparison, despite seemingly lax supervision, was and remains competitive, engaging domestic and foreign banks in avid competition for local customers. The much larger domestic interest rate margin in Iceland than in Ireland reflects the oligopolistic inefficiency and excesses marring Icelandic banking before as well as after privatization (Figure 9).

Figure 9. Interest rate spread 1970-2009 (Lending rate minus deposit rate, \%)

Nordics

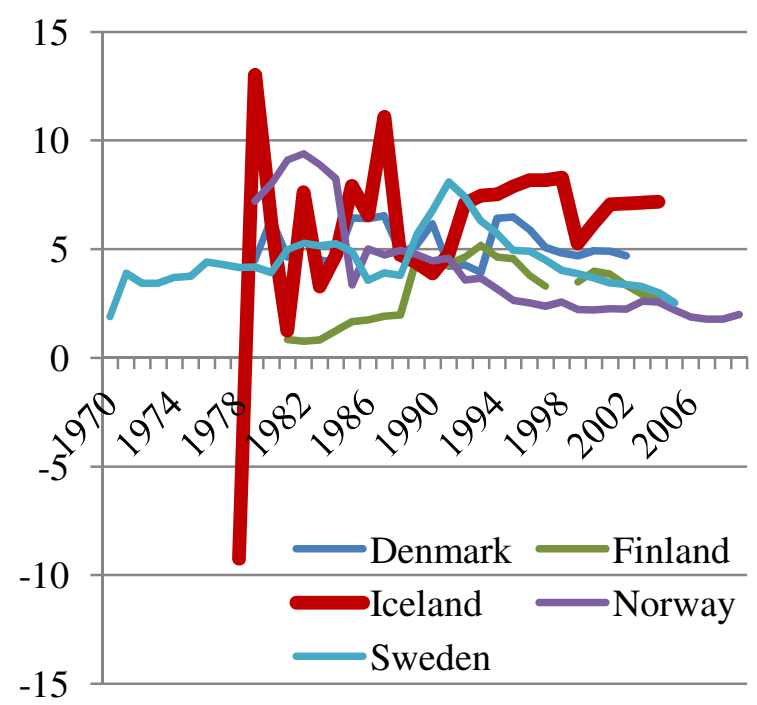

Periphery

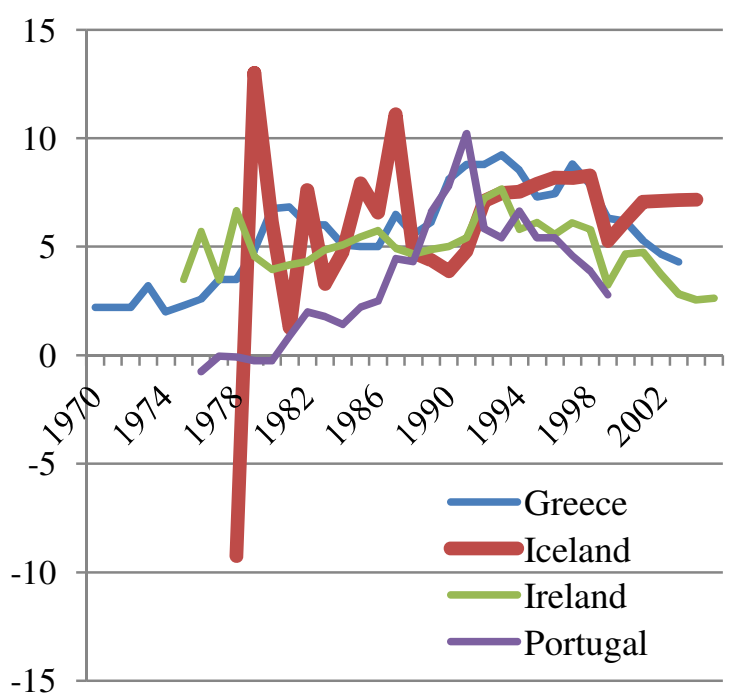

Under normal conditions, the aim of privatization is to make banks more efficient for the benefit of their customers and the community by, for example, reducing the interest rate spread, a simple measure of bank efficiency. In Iceland, however, the interest rate spread did not decrease following the banks' privatization in 1998-2003. On the contrary, the spread increased and remained far above foreign levels. Without foreign competition, the Icelandic

\footnotetext{
${ }^{22}$ The Independence Party has been in government nearly 80 percent of the time since 1944 .
} 
banks got away with continuing to squeeze their captive customers, borrowers as well as lenders. In Greece, Ireland, and Portugal, on the other hand, as well as in the rest of the Nordic region, local banks faced foreign competition from, among others, Icelandic banks.

Plainly, the Icelandic banks like the Irish ones borrowed too much. But there are two parties to every transaction. What were the creditors of the banks thinking? They had been led to believe that the government stood behind the banks. Rating agencies and accounting firms failed to warn of pending dangers. Unlike in Ireland where the government decided to bail out the banks at huge cost to Irish taxpayers and to the pace of economic recovery, the Icelandic government abandoned the banks (Gylfason, 2013a). There was no other way out because the hole that the banks had dug themselves into while the government looked the other way or even egged them on was too deep. ${ }^{23}$ Had the scale of the problem been smaller, the Icelandic government might have done what the Irish government did, but that was not an option. So, there was nothing particularly courageous or virtuous about Iceland's "standing up to" foreign banks. The road taken was necessary and inevitable.

In 2011, the Supreme Court upheld the emergency laws enacted during the 2008 crash to ensure that domestic depositors had priority over other claims on the assets of the failed banks. The ruling facilitated the settlement of Iceland's Icesave debt ${ }^{24}$ to the governments of the United Kingdom and the Netherlands that had paid partial compensation to British and Dutch Icesave depositors, a settlement first approved by Parliament in two rounds only to be rejected twice in national referenda, and ultimately dismissed on technical grounds by the EFTA court, the final arbiter of the case.

Five years after the crash, the Icelandic banks, still the only game in town, again make huge profits by local standards. They have resumed the payment of bonuses to their senior staff.

\footnotetext{
${ }^{23}$ Shortly before the crash, Icelandic ministers and bank directors appeared side by side at meetings with creditors in London and New York to reassure them that everything was under control.

${ }^{24}$ Icesave is the Landsbanki branch that, when liquidity began to dry up, went on to collect high-interest internet deposits in the UK and the Netherlands from some 400,000 depositors during 2006-2008, and then collapsed.
} 
They have written off huge amounts of loans, mostly to firms, ${ }^{25}$ thus alleviating their need to lay off workers and in some cases enabling some of the major local players before the crash to stay in business. Even after huge write-offs, in 2011, the banks' nonperforming loans are equivalent to almost a quarter of their total assets (Figure 10). ${ }^{26}$ The banks remain overstaffed. In 2012, the Icelandic banks employed 11.6 full-time staff per one thousand inhabitants compared with 8.1 in Denmark, 5.3 in Finland, 4.5 in Norway, and 3.6 in Sweden. ${ }^{27}$ At the same time, the banks have become more vigilant. Loans without collateral - common before the crash - and other one-way bets against the banks are reportedly no longer made, or tolerated.

Figure 10. Bank nonperforming loans 2000-2012 (\% of gross loans)

Nordics
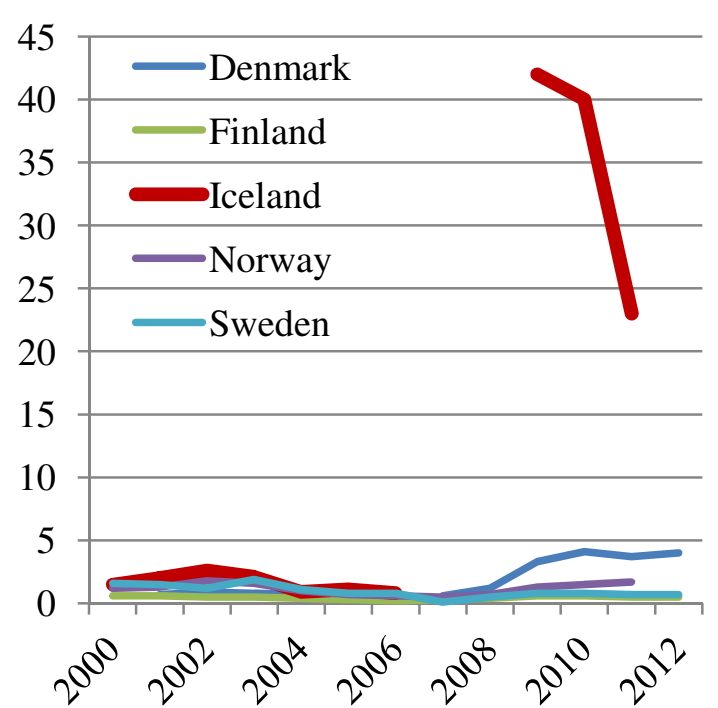

Periphery

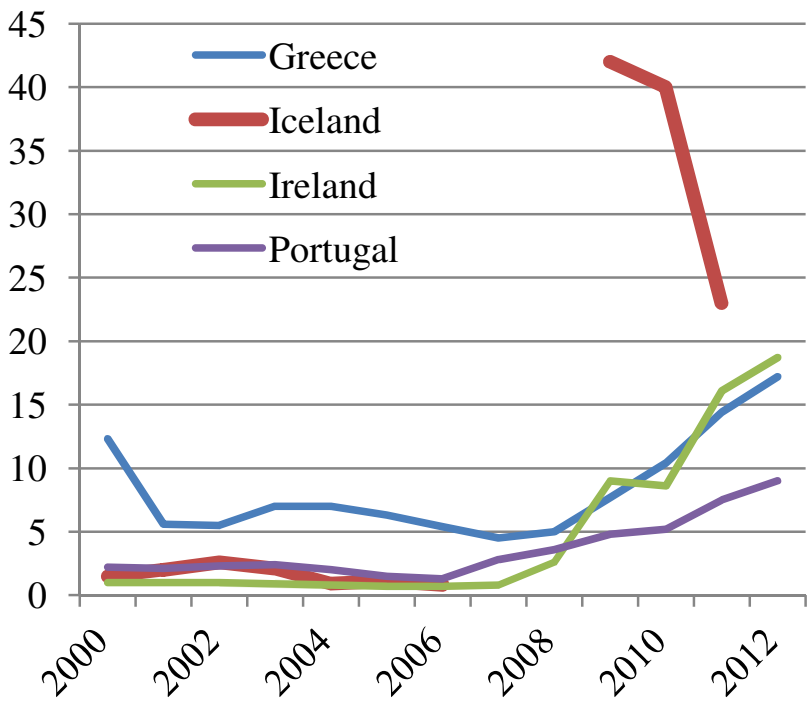

On the whole, the behavior of the banks after the crash has not helped endear them to many of their customers. Public opinion research by MMR (Market and Media Research) and Capacent, an affiliate of Gallup, shows that the banking system enjoys less trust than any

\footnotetext{
${ }^{25}$ Through deleveraging and write-offs, household debt has fallen by $14 \%$, in part because the Supreme Court ruled that the indexing of loans to foreign currencies was illegal, and corporate debt has fallen by $45 \%$ (IMF, 2013), partly through concerted action by the government, financial institutions, and employers' associations. Following the Nordic financial crisis of 1988-1993, household debt in Finland and Sweden fell by $30 \%$. ${ }^{26}$ Nonperforming loans on a facility basis fell from a peak of $18 \%$ at end-2010 to $6 \%$ at end-2012. On a crossdefault basis Fig. 8 classifies as nonperforming all loans to borrowers with at least one loan in default. Data for Iceland 2007-2008 and 2012 (and Norway 2012) are not reported by the IMF, the source quoted by the Word Bank's World Development Indicators. Recall footnote 6.

${ }^{27}$ Source: Finanssektorens Arbejdsgiverforening (2012).
} 
other public institution in Iceland (Figure 11). If any reputable foreign bank were to open offices in Iceland, it seems safe to assume that they would not face any shortage of local customers. Trust in Parliament declined from 40 percent in 2008 to 14 percent in 2013.

Figure 11. Trust in Icelandic institutions 2013 (\% expressing a lot of trust in institutions)

$M M R$
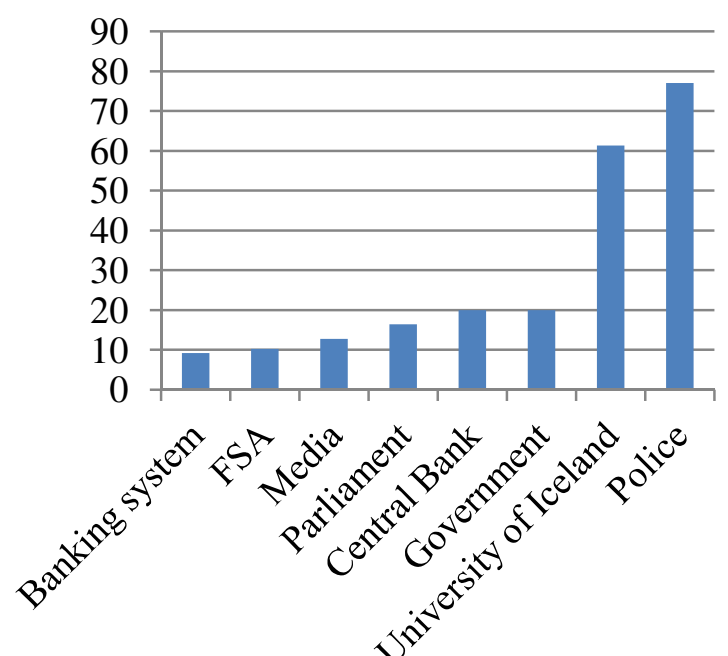

Capacent
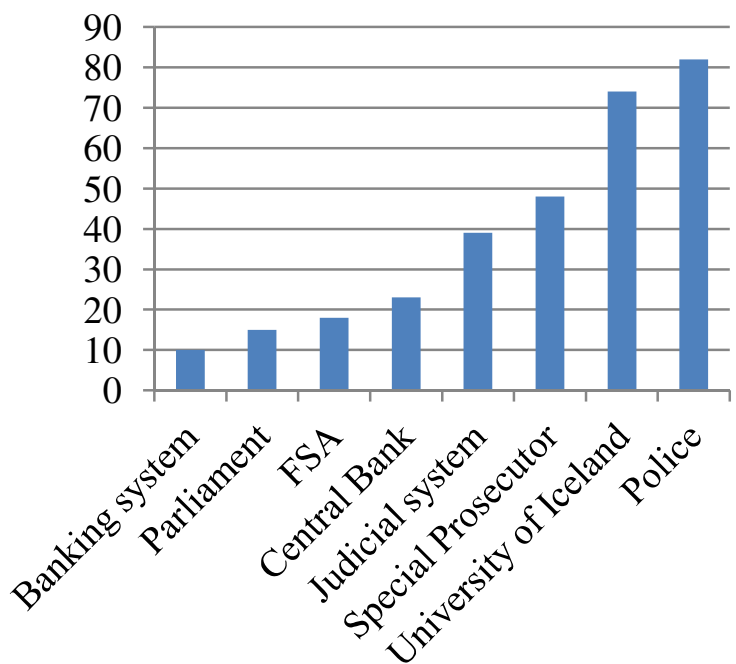

Figure 12. Corruption 2012 (Business corruption as measured by Transparency, political corruption as measured by Gallup)

Transparency

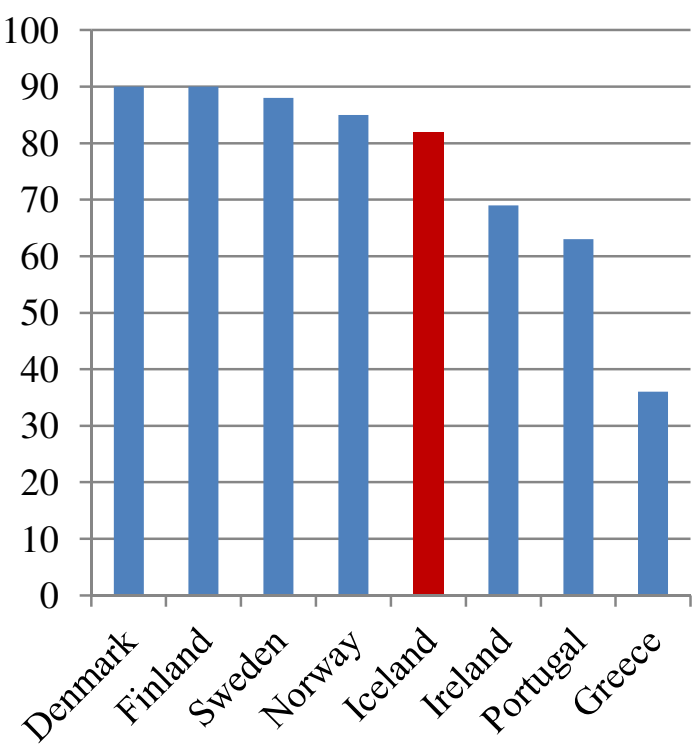

Gallup

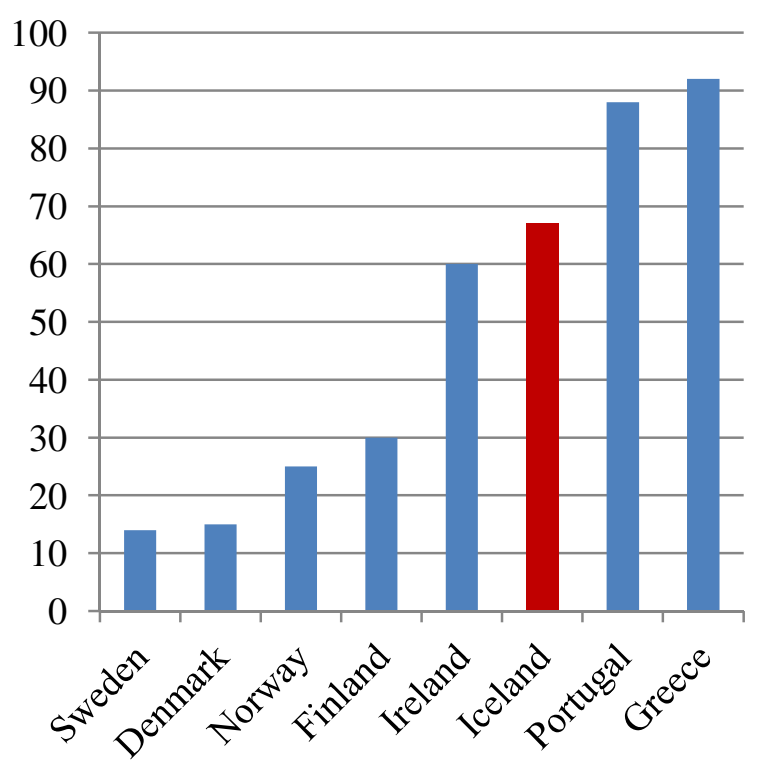

Readers of Transparency International's compilation of the corruption perceptions index may have noticed that Iceland does not lie far behind the rest of the Nordics (Figure 12). 
Transparency covers business corruption, bribes and such; the higher the index, the less corrupt the country is perceived to be. Figure 12 also shows the results of a recent Gallup poll where a large sample of voters in 129 countries was asked the following question: "Is corruption widespread throughout the government of [your country], or not?" Two thirds of the Icelandic respondents consider their government corrupt compared with a fifth on average in the rest of the Nordics. Many people in government pretend not to have noticed, or, when presented with the evidence, react like French police captain Louis Renault in Casablanca who was "shocked - shocked! - to find that gambling is going on in here."

There is nothing new in this. Before the crash, however, there was not much talk of corruption in public debate. A common if unspoken attitude was that if corruption was a problem it was affordable because, with living standards comparable to the rest of the Nordics, Iceland seemed to be doing quite well. The crash changed the rules of the game. With Iceland's living standards now far behind the rest of the Nordics and with uncertain prospects for recovery, past and present corruption is on the table. Among the most glaring form of corruption in Iceland has been appointment corruption, including nepotism, by which incompetent people are appointed to public office - in ministries, public agencies, banks, courts, etc. ${ }^{28}$ Five years after the crash, the problem persists. This is why the constitutional bill drafted and unanimously approved by a directly elected Constitutional Council and subsequently accepted by two thirds of the voters in a national referendum in 2012 features special provisions on the appointment of judges and other public officials. ${ }^{29}$ Reykjavík elected as mayor in 2010, 18 months after the crash, a comedian whose winning slogan was: We will not keep our corruption from you! All this matters because respect for democracy, trust, and the absence of corruption are essential ingredients of social capital (Paldam, 2000) and thereby important

\footnotetext{
${ }^{28}$ In 2011, the Supreme Court of Iceland awarded damages to an unsuccessful applicant for a district judgeship to which a close relative of a former Prime Minister, Foreign Minister, and Central Bank governor had been appointed.

${ }^{29}$ The bill has been put on ice by Parliament in a blatant attempt to thwart the will of the people.
} 
sources of economic growth.

\section{Growing together or growing apart?}

How did Iceland get into this remarkable mess? From the 1930s onward Iceland, like the Republic of Ireland excluding Northern Ireland, was among the most conservative, regulated, and inward-looking societies in Western Europe. From the 1920s onward, for example, to protect its farmers, Iceland prohibited the importation of dairy products and meat, a ban still essentially intact. In other respects as well, throughout the $20^{\text {th }}$ century, policies tended to favor farmers and other inhabitants of rural areas, a rather conservative social force. Rural areas were granted disproportionate political clout through an election system where it took far more votes to be elected to Parliament in the Reykjavík area, now home to two thirds of the country's population, than it took in some rural areas. While the overrepresentation of rural areas in Parliament has been reduced over time, the problem persists: to be elected, some rural candidates still need only half as many votes as do candidates from the Reykjavík area. This is why one of the main provisions of the afore-mentioned constitutional bill stipulates 'one person, one vote,' a provision supported by two thirds of the voters in the 2012 referendum, casting doubt on the legitimacy of future parliamentary elections according to rules that the voters have rejected. Outward-looking, efficiency-oriented social democracy never took root in Iceland, or in Ireland, unlike in Scandinavia and the United Kingdom.

Let us take a quick look at exports, investment, and education, all important determinants of long-run growth. For a long time, Iceland has fared comparatively poorly by all three measures. Iceland was hampered by stagnant exports relative to GDP until the króna's perennial overvaluation ended with its collapse in 2008, enabling exports at long last to make some headway (Figure 13). At about a third of GDP since 1960 (in fact, since 1870, but leave that aside), Iceland's export ratio has been low in view of the small size of its economy.

Figure 13 demonstrates the stimulating effect that a depreciation of the currency - in this case, 
by a third in real terms - can have on export earnings which have doubled relative to GDP.

Notice also the sharp recovery of Irish exports despite the euro.

Figure 13. Exports of goods and services 1960-2012 (\% of GDP)

Nordics

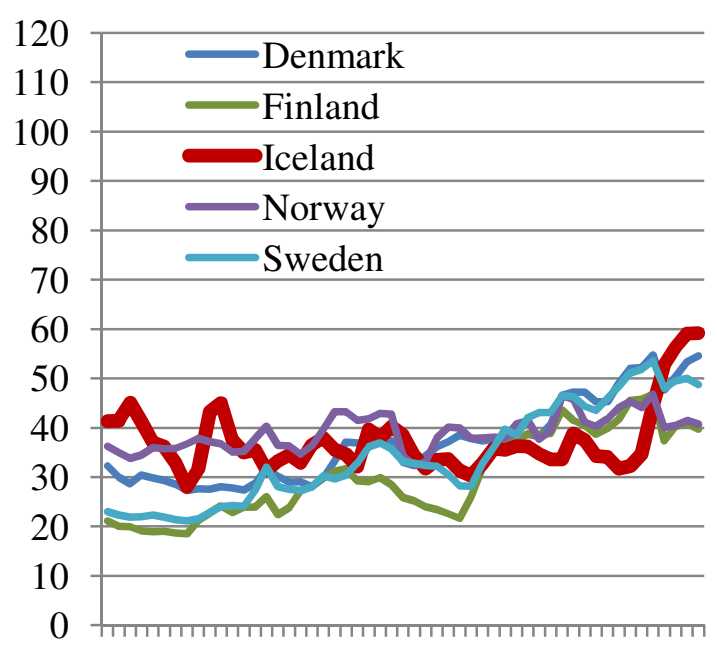

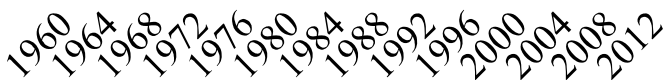

Periphery

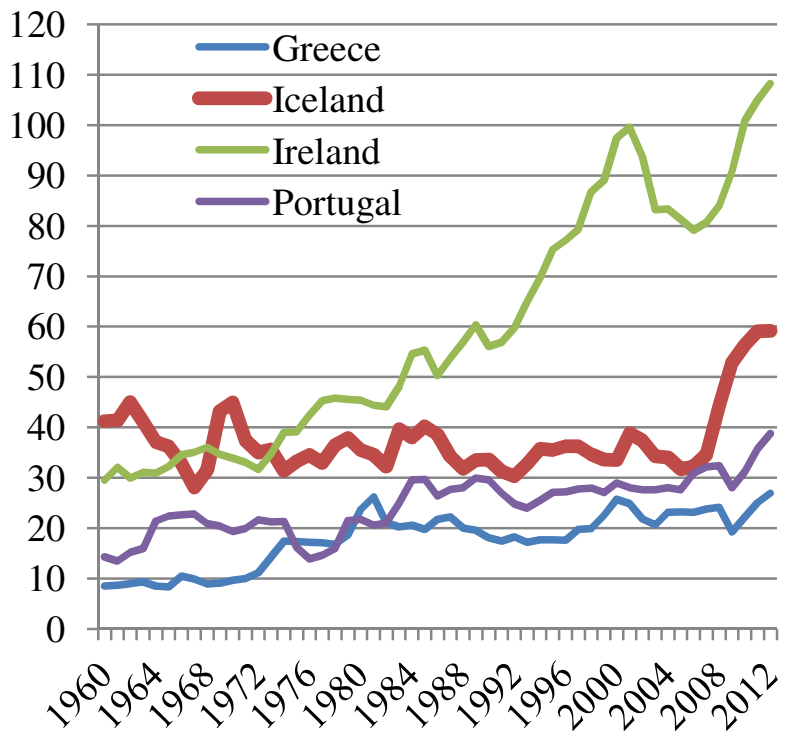

The behavior of imports is also worth noting. In Iceland, the volume of imports rose by 80 percent from 2000 to 2008 after which it collapsed below its 2000 level, by far the most extreme pattern of import behavior in the countries under comparison (Figure 14). The fact that import volume contracted by 44 percent after the crash while output fell by 10 percent suggests a strong effect of the depreciation of the currency on imports in Iceland. Greece, Ireland, and Portugal also experienced a sharp decline in imports.

The composition of Iceland's exports remains less growth-friendly than in Denmark, Finland, and Sweden as well as in Ireland and Portugal where manufactures comprise the bulk of merchandise exports (Figure 15). With a few exceptions (e.g., artificial limbs, computer games, fish processing equipment, and generic drugs), Iceland's exports are on the whole remarkably low-tech. In 2012, fish products accounted for 27 percent of total export earnings, aluminum for another 22 percent, and foreign tourism 24 percent (source: Statistics Iceland). Figure 15 also shows the sharp relative decline of Norway's manufacturing exports as a result 
of crowding out, a common symptom of the Dutch disease in natural resource rich countries.

Figure 14. Import volume 2000-2011 $(2000=100)$

Nordics

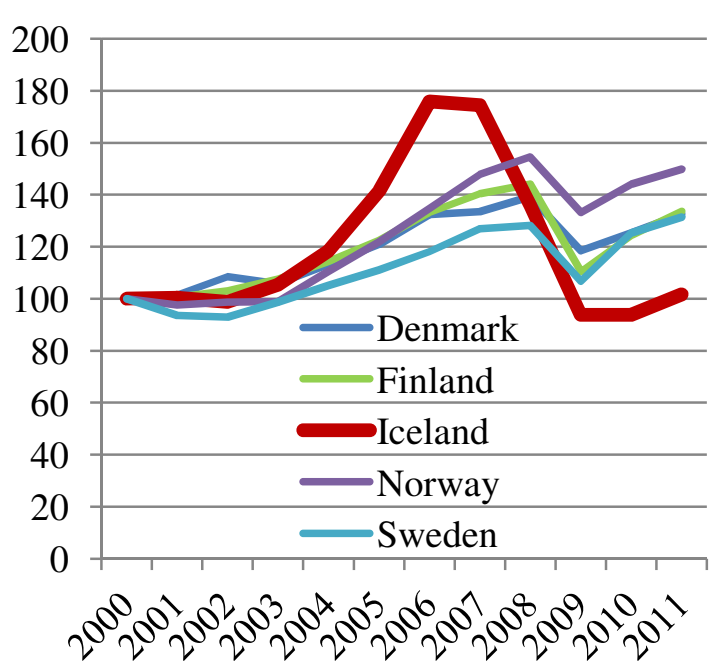

Periphery

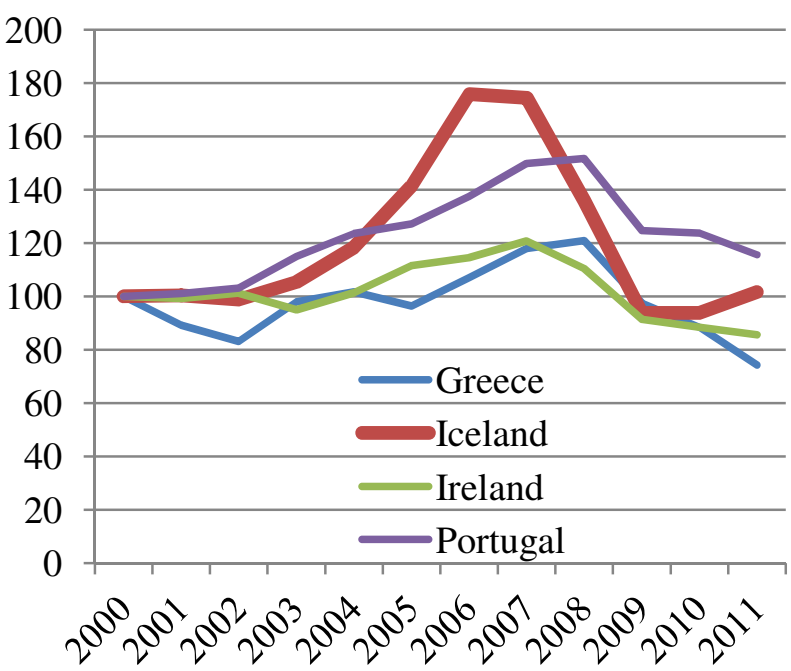

Figure 15. Manufactures exports 1962-2012 (\% of total exports)
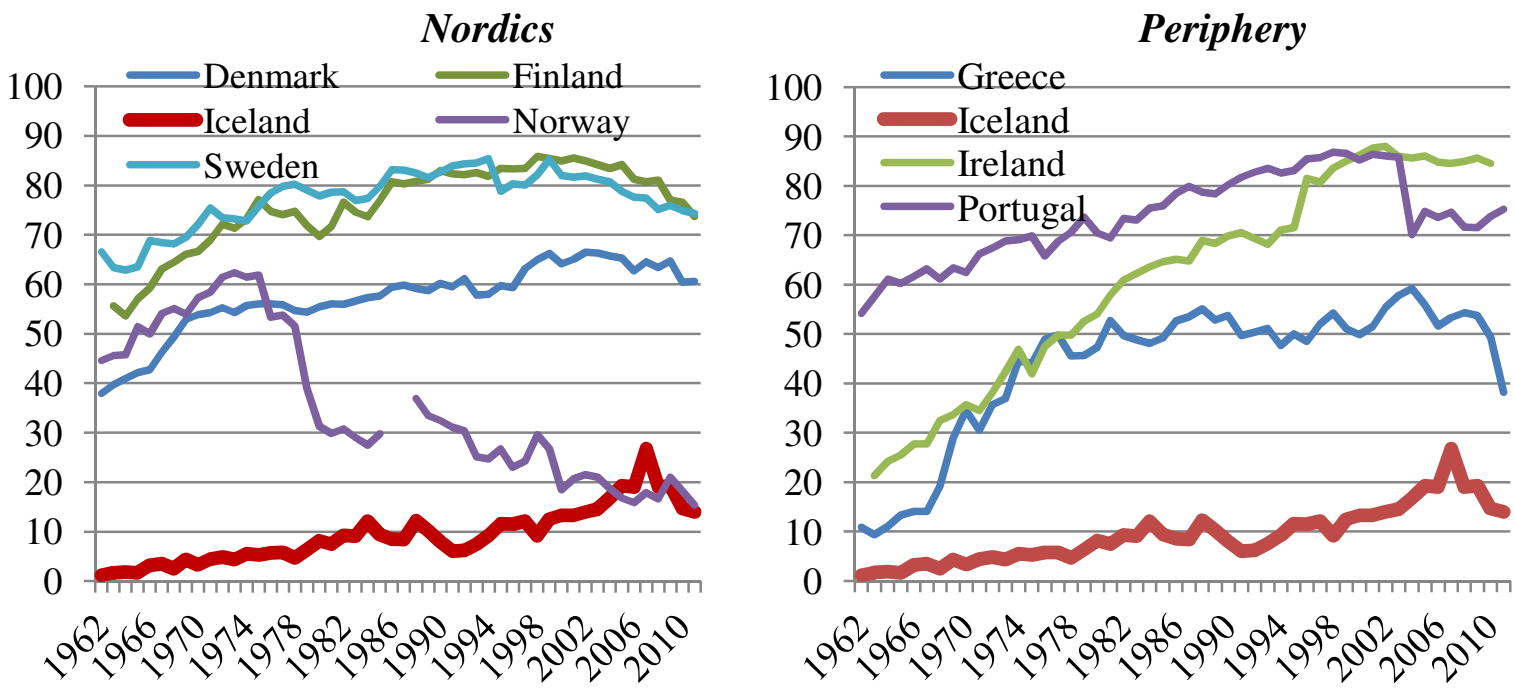

Iceland's exports of fish and aluminum render its export structure highly concentrated (Figure 16); the Iceland figures compare with those Saudi Arabia and Nigeria (not shown). Further, it is interesting to note that Norway used its oil wealth to build up a Pension Fund of more than $\$ 800$ billion, invested overseas, the world's largest, equivalent to nearly $\$ 180,000$ per person in Norway, while Iceland carries a crushing debt burden despite abundant fish and energy 
resources. Export concentration sometimes translates into concentration of political power, a problem that Norway judiciously avoided but Iceland did not (Gylfason, 2013a).

Figure 16. Herfindahl merchandise export diversification index 1995-2012

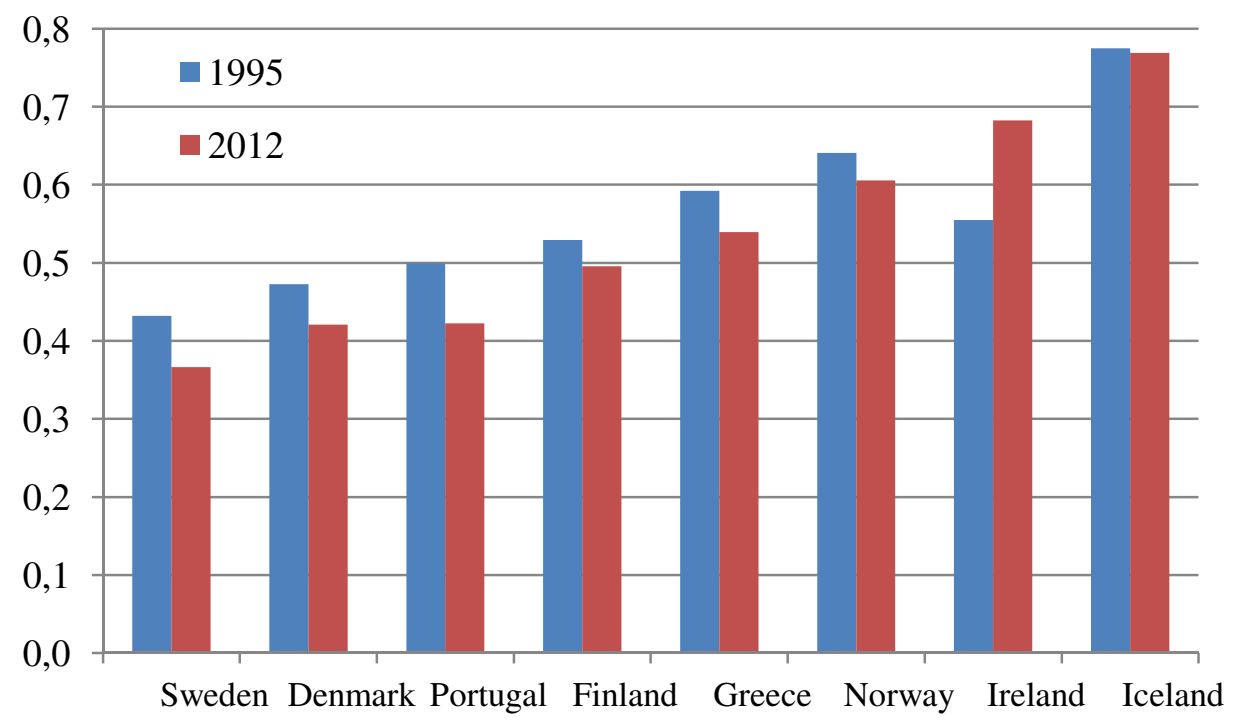

Note: The diversification index shows how the structure of exports by product of a given country differs from the world average. The index ranges from 0 to 1 , with values closer to 1 indicating a bigger difference from the world average.

Figure 17. Gross investment 1965-2011 (\% of GDP)

Nordics

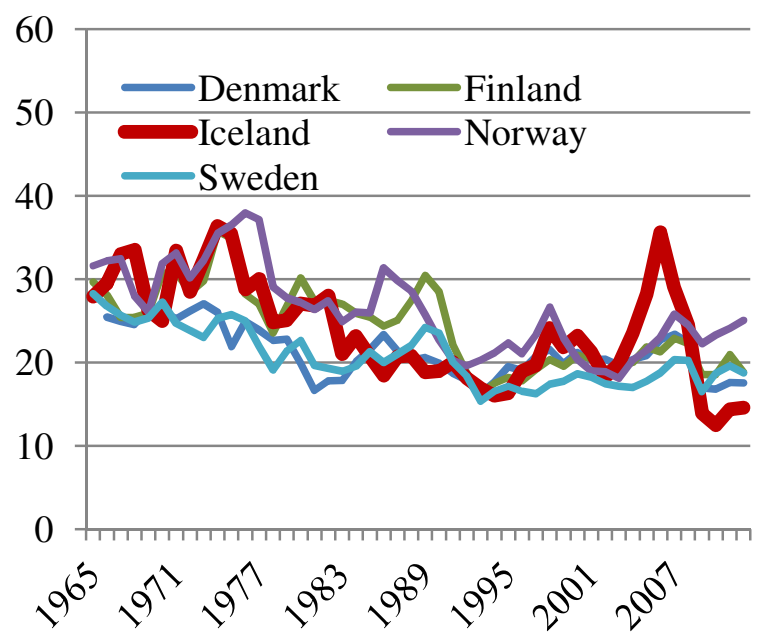

Periphery

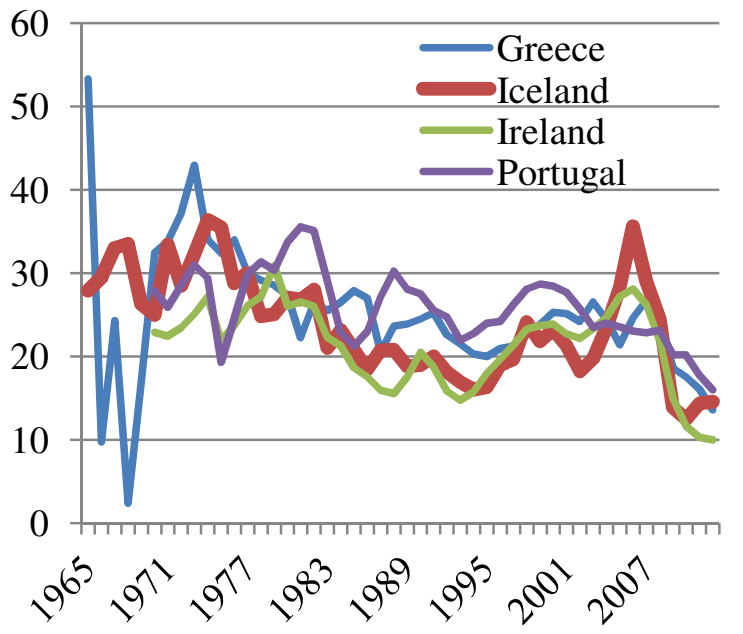

Investment in machinery and equipment as well as construction boomed before the crash of 2008 and then collapsed (Figure 17), so much so that net investment - that is, gross

\footnotetext{
${ }^{30}$ Source: UNCTAD.
} 
investment less depreciation - was negative from 2009 to 2012. This means that the physical capital stock declined four years in a row. Since the crash, foreign investment has been insignificant because potential investors lost confidence besides being discouraged by strict capital controls in effect since late 2008 with no end in sight.

Investment in human capital is described in Figures 18-20. Iceland has long had and still has a comparatively poorly educated labor force of which a relatively large proportion has at most acquired primary education (Figure 18) and of which a correspondingly small proportion has acquired secondary education (Figure 19) and tertiary education (Figure 20).

Figure 18. Labor force with primary education 1992-2011 (\% of total)
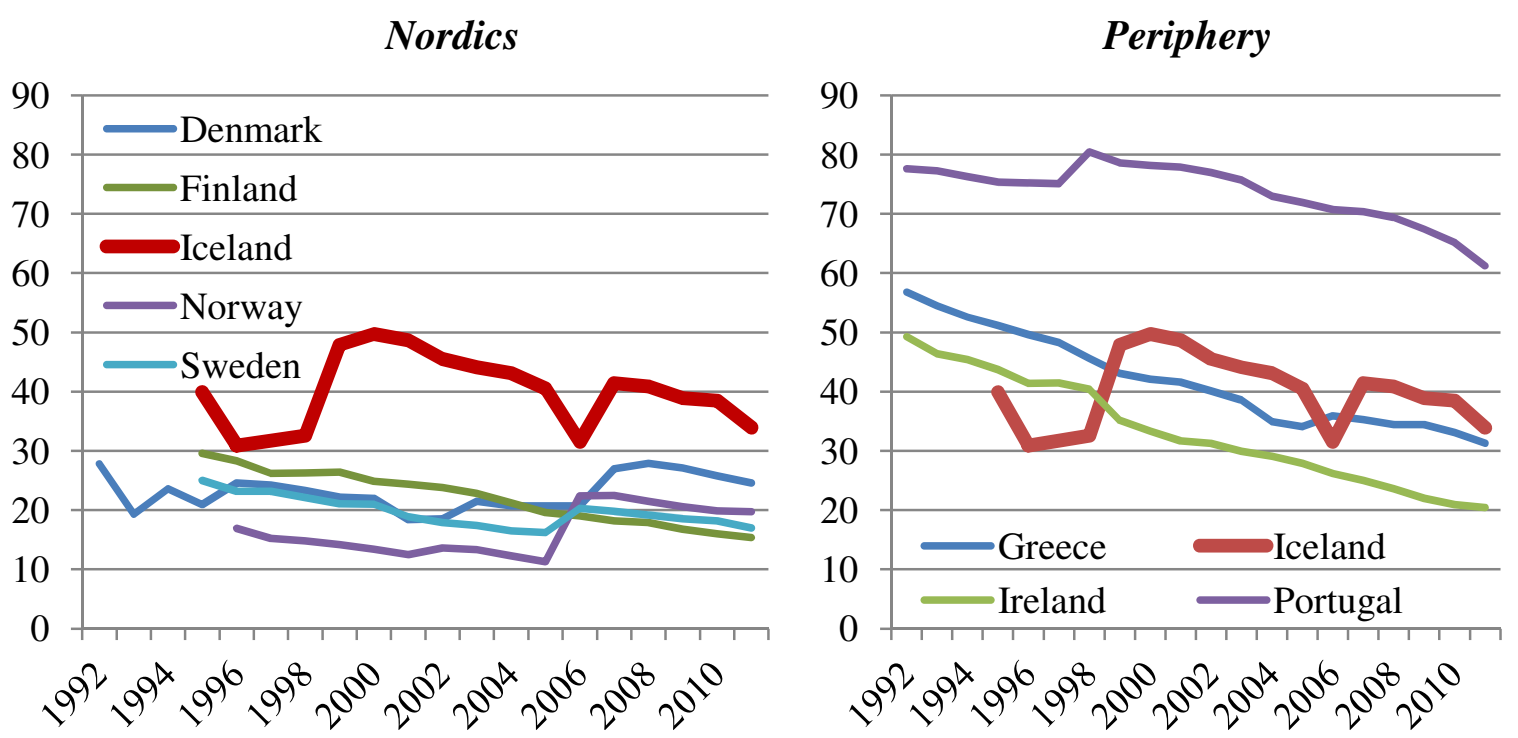

In the group of countries under review, only Portugal has a less well educated labor force than Iceland. ${ }^{31}$ Other indicators point to the same conclusion. For example, in 2009, public expenditure per student at the tertiary level (college and university) amounted to 30 percent of per capita GDP in Iceland compared with 57 percent in Denmark, 39 percent in Finland, 49

\footnotetext{
${ }^{31}$ Based on a stochastic frontier model, the IMF (2013, Annex II) suggests that Iceland's labor productivity lags only slightly behind its Nordic neighbors (and exceeds that of European countries) while acknowledging that efficiency ratings have declined in recent years, "underscoring the need to improve resource allocation and address legacy vulnerabilities, ... including the imposition of capital controls and a weak banking system."
} 
percent in Norway, 45 percent in Sweden, 38 percent in Ireland, and 31 percent in Portugal. ${ }^{32}$

The curriculum also matters. Polishchuk and Natkhov (2012) argue that corruption tends to direct students from science to legal studies, reporting that, in Ukraine, relatively many more students study law than in Poland where many more students study science than in Ukraine. In Iceland, they also report, relatively many more study law than in Denmark, Finland, Norway, and Sweden while, in the latter group, many more study science than in Iceland.

Figure 19. Labor force with secondary education 1992-2011 (\% of total)

Nordics

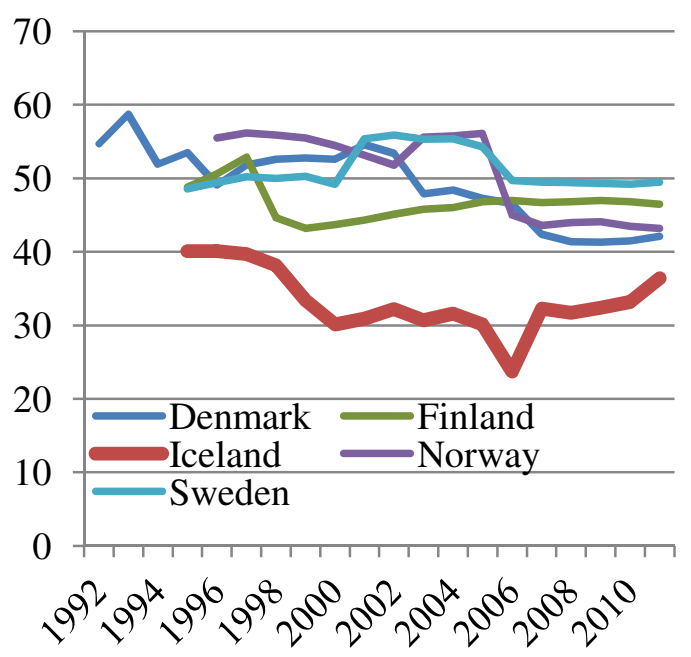

Periphery

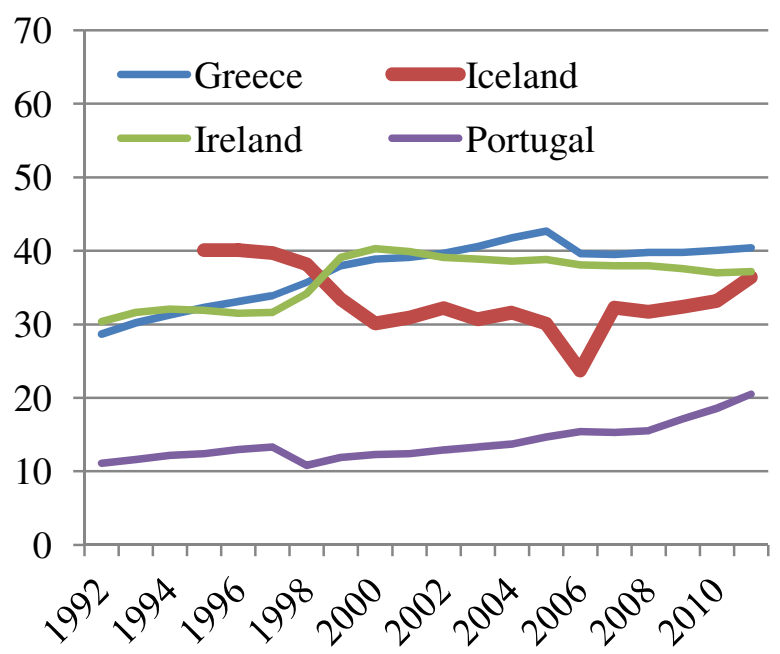

Figure 20. Labor force with tertiary education 1992-2011 (\% of total)

Nordics

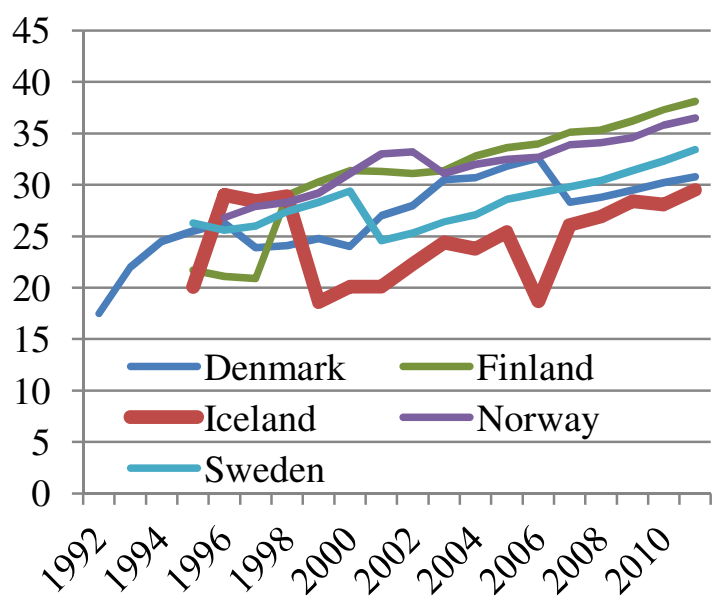

Periphery

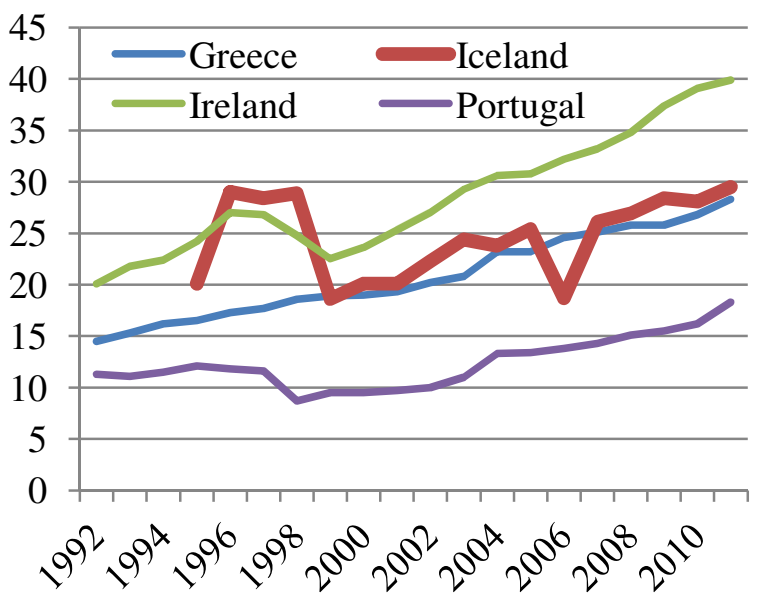

In sum, Iceland's relatively weak performance for quite some time in terms of foreign trade

\footnotetext{
${ }^{32}$ Source: UNESCO Institute for Statistics; figures on Greece are not available.
} 
(Figures 13-16) as well as in terms of the buildup of real capital (Figure 17), human capital (Figures 18-20), and social capital (Figures 11-12) may help explain the deterioration of its overall economic position within the Nordic group as well as the need for long hours of work (Figures 1-4). If so, Iceland's present predicament may not be just a consequence of the crash of 2008 and its aftermath, but also of neglectful policies with deep roots in a political culture that Parliament has unanimously resolved to do something about. It remains to be seen if the political class will keep its promise.

\section{Miles to go}

How long will it take Iceland to regain economic and social parity with the rest of the Nordics? This is impossible to know. For one thing, no one knows how long the capital controls will remain in place, controls that were originally thought to be needed for two to three years but have become firmly entrenched as their abolition, especially if disorderly, would cause the króna to depreciate further, perhaps by 20 percent or 30 percent or more, something the government wants to avoid. Yet, the controls are incompatible with Iceland's membership in the European Economic Area except as a temporary emergency measure.

The government that took office in 2013 unilaterally withdrew from Iceland's accession negotiations with the EU in process since 2009. Further, no one knows if the political class will revert to its old habits now that the IMF has left the scene. The Central Bank repaid two thirds of the IMF loan with borrowed money ahead of schedule, something that countries sometimes do to avoid unwelcome post-crisis attention from the Fund. The government promises significant household debt relief (on top of the write-downs already provided by the banks) without specifying clearly how this will be financed, ignoring the IMF's warnings that this may make inflation go up. Further, the regressive policy stance of the government, witnessed, for example, by its generosity to vessel owners who were, again against IMF opposition, excused from paying higher fishing fees planned by the preceding government of 
2009-2013, may trigger compensating wage demands. The IMF (2013) warns in carefully coded language that "legacy vulnerabilities are creating headwinds." The Prime Minister refers to the IMF as a "foreign acronym."

Despite deleveraging through repayment, write-offs, and significant government help to distressed households, many households and firms remain in dire straits. For many wage earners the problem is that their indexed mortgages increased far more than their wages. ${ }^{33}$ For many small and medium-sized firms the problem is that they are effectively bankrupt despite considerable debt restructuring. ${ }^{34}$ For the government the problem is that allowing moderate inflation to deflate debts is a sensitive issue in a high-inflation country that introduced financial indexation some 30 years ago in reaction to the inequitable consequences of high inflation for borrowers and lenders. The government has not yet announced any plans for the future organization and ownership of banks in Iceland.

Clouds are gathering, yes, but amid rays of sunshine. With help from the IMF, Nordic governments, and Poland, Iceland avoided sovereign default after the crash and is growing again (recall Figure 1), but slowly, by about one percent per year or so per capita. The IMF (2013, Annex III) reckons that Iceland's foreign debt and public debt is on a sustainable path, even if "risks remain elevated." Many observers are encouraged by the Special Prosecutor's ability to let some of the culprits behind the crash face justice. Economics and law, efficiency and justice, must go hand in hand. Economic recovery is not enough. There is a need for accountability, responsibility, and transparency, and all three run like a red thread through the constitutional bill approved by the voters in 2012 only to be hijacked by a Parliament that openly flirts with, and even flaunts, the idea of contravening the popular will as expressed in the 2012 referendum as if no referendum had taken place (Gylfason, 2013a, 2013c).

\footnotetext{
${ }^{33}$ In 2012, about one in four Icelandic households had negative equity in their homes compared with roughly a half of Irish households.

${ }^{34}$ A bit more than a quarter of the 2,700 qualified SMEs accepted debt restructuring along the lines agreed by the government, financial institutions, and employers ' associations (recall footnote 25).
} 
Financial crises never destroy countries - firms, yes, people, sometimes, but not nations, for they always survive, even after they default on their debts, which Iceland did not. Financial wealth is such a small fraction of total national wealth that a financial crash, even the deepest plunge, rarely puts a big dent in national wealth because by far the most important part of a nation's total wealth is human resources and social capital. Financial wealth typically constitutes only about four percent to five percent of total national wealth (World Bank, 2006). So, for a financial crash to do deep and lasting economic damage, it needs to destroy human capital or social capital by, for example, triggering a mass exodus of people or seriously undermining the country's institutions, including democracy.

The fear of mass migration has subsided. From 2009 to 2012, net emigration from Iceland amounted to less than three percent of the population compared with less than two percent in Ireland 2008-2012. "Ireland does not exist in vain as long as she produces sons and daughters with sense enough to leave her," said George Bernard Shaw, the Irish playwright. That was then. For the most part, Iceland's social indicators were unaffected by the crisis. Suicides did not increase in number. Life expectancy shows no signs of going down, even if poverty has never been as visible as after the crash.

Both Iceland and Ireland have more than enough economic potential to be able to hold on to their human resources. A declaration of victory over the crash would be premature, however. O'Toole's (2009) description of Ireland as a first-world country with a third-world political culture characterized by deep-seated cronyism and other forms of corruption also fits Iceland even if details differ. For example, bank loans to building contractors played a larger role in Ireland than in Iceland. While in Ireland real estate prices rose by a factor of more than six from 1994 to 2006 , or by over 16 percent per year on average, apparently a world record, in Iceland they rose by a factor of 2.5 from 2001 to 2008 or by 11 percent per year on average. Even so, the broad contours of the economic, political, and historical background are similar 
in both countries, including a legacy of foreign dominance that bred a lack of selfresponsibility and accountability in the local elites that emerged in the $20^{\text {th }}$ century, a problem shared by many African countries and others, but not by Finland. Both Iceland and Ireland were bound to collapse regardless of the fate of Lehman Brothers (Gylfason, 2013b).

Another relevant comparison is that between Iceland and the Faroe Islands whose economic crash 1989-1993 made GDP contract by a third, a unique event in Western Europe in peacetime that triggered the emigration of 15 percent of the population. ${ }^{35}$ The root cause of both collapses was essentially the same, that is, a dire lack of checks and balances to protect the people against corruption in the form of cozy - some would say incestuous - relations among banks, business, and politics (Jónsson, 1994). In effect, both countries are client states, subordinate de facto to shifting states within the state - bank owners, boat owners, land owners, various interest organizations - with rampant rent capture, regulatory capture, media capture, academic capture, ${ }^{36}$ and so on.

Remarkably, the Faroe Islands emerged from their deep plunge with an external debt to Denmark equivalent to 120 percent of GDP that they were able to repay with interest within six to eight years. The Faroe Islanders have taken significantly less financial support from Denmark after the crash than before. Apart from the net loss of ten percent of the population, the crisis in the Faroe Islands 20 years ago seems not to have seriously dented the country's social capital, with one qualification. The Parliament promised the people a constitution as well as a national referendum on that constitution, a fine bill prepared by a committee appointed by Parliament, but the referendum remains to be held. The politicians, including some of those who pushed the country off the cliff in 1989, have hijacked the constitutional bill, mainly, it seems, due to a provision guaranteeing nondiscriminatory natural resource

\footnotetext{
${ }^{35}$ A third of the emigrants returned within a few years, so net emigration amounted to $10 \%$ of the Faroese population, still a significant shock.

${ }^{36}$ For examples, see Ferguson (2012, Ch. 8).
} 
management designed to honor the basic principle of human rights that the country's natural resources belong to the people (Wenar, 2008). Such a provision was deemed necessary to ensure equal access of all citizens to the nation's natural resources or to a fair share of the proceeds from the resources as opposed to the selective allocation of valuable commonproperty fishing rights to a privileged few along Icelandic lines that were ruled unconstitutional by the Supreme Court of Iceland in 1998 as well as by the United Nations Committee on Human Rights in 2007 (Gylfason, 2012). The ongoing stalemate in the Faroe Islands between the rent seekers and the rest of the people remains unresolved.

In Iceland, after the crash of 2008, Parliament promised a new constitution and a national referendum on that constitution. A constitutional bill with a provision guaranteeing nondiscriminatory natural resource management was drafted and unanimously approved by a directly elected Constitutional Council. ${ }^{37}$ The bill was subsequently accepted by two thirds of the voters in a national referendum as was the provision stipulating 'one person, one vote.' Further, the nondiscriminatory natural resource management provision was approved by 83 percent of the voters. Even so, in a direct affront against democracy, Parliament hijacked the bill as if no referendum had taken place. It is one thing not to hold a promised referendum on a parliamentary bill as was done in the Faroe Islands. It is quite another thing to disrespect the overwhelming result of a constitutional referendum by putting democracy on ice as is now being attempted in Iceland by putting a new constitution already accepted by the voters into the hands of a parliamentary committee chaired by a sworn enemy of constitutional reform as if no referendum had taken place (Gylfason, 2013c). Parliament is playing with fire. It risks the demotion of Iceland from the club of full-fledged democracies. A threat against democracy is a threat against social cohesion and peace and, by extension, against continued

\footnotetext{
${ }^{37}$ Three individuals with connections to the Independence Party filed technical complaints about the Constitutional Council election which led six Supreme Court justices to nullify the results of the election even if it was acknowledged that the alleged technical flaws could in no way have affected the results. Five of the six justices in question were Independence Party appointees. Parliament responded by appointing the elected representatives to the Council, including the author.
} 
recovery and reform-based long-run growth. Rebuilding social capital is not easy if the preceding corrosion took the form of squandered trust. It is still too early to foretell the effects of Iceland's financial crash on its social capital.

\section{References}

Akerlof, George A., and Paul M. Romer (1993), "Looting: The Economic Underworld of Bankruptcy for Profit,“ Brookings Papers on Economic Activity 2, pp. 1-73.

Aliber, Robert Z., and Gylfi Zoega (eds.) (2011), Preludes to the Icelandic Financial Crisis, Palgrave MacMillan.

Benediktsdóttir, Sigríður, Jón Daníelsson, and Gylfi Zoega (2011), “Lessons from a Collapse of a Financial System,” Economic Policy, Vol. 26, No. 66, pp. 183-235, April.

Black, William K. (2005), The Best Way to Rob a Bank Is to Own One: How Corporate Executives and Politicians Looted the S\&L Industry, University of Texas Press.

Blinder, Alan S. (2013), After the Music Stopped: The Financial Crisis, the Response, and the Work Ahead, Penguin Press.

Ferguson, Charles H. (2012), Predator Nation: Corporate Criminals, Political Corruption, and the Hijacking of America, Crown Business.

Finanssektorens Arbejdsgiverforening (2012), Nordic Bank Statistics, October.

Galbraith, John Kenneth (1988), The Great Crash 1929, Houghton Mifflin Company.

Galbraith, James Kenneth (2012), Inequality and Instability: A Study of the World Economy Just Before the Great Crisis, Oxford University Press.

Gylfason, Thorvaldur (1995), Síðustu forvöð (High Time), Iceland University Press, Ch. 9. In Icelandic.

Gylfason, Thorvaldur (2008), “When Iceland was Ghana,” VoxEU, 28 January.

Gylfason, Thorvaldur (2009), “Is Iceland too Small?” VoxEU, 19 August.

Gylfason, Thorvaldur (2010), "Mel Brooks and the Bankers,” VoxEU, 18 August. 
Gylfason, Thorvaldur, Bengt Holmström, Sixten Korkman, Hans Tson Söderström, and Vesa Vihriala (2010), Nordics in Global Crisis, The Research Institute of the Finnish Economy (ETLA), Taloustieto Oy.

Gylfason, Thorvaldur (2012), “Constitutions: Financial Crisis Can Lead to Change,” Challenge, September-October, pp. 106-122.

Gylfason, Thorvaldur (2013a), "From Collapse to Constitution: The Case of Iceland," in Luigi Paganetto (ed.), Public Debt, Global Governance and Economic Dynamism, Springer Verlag, pp. 379-417.

Gylfason, Thorvaldur (2013b), “A Tale of Two Debtors: Iceland, Ireland - and Their Banks,” Milken Institute Review, April.

Gylfason, Thorvaldur (2013c), "Democracy on Ice: A Post-mortem of the Icelandic Constitution," http://www.opendemocracy.net.

Honkapohja, Seppo (2009), “The 1990’s Financial Crises in Nordic Countries,” Bank of Finland Research Discussion Papers No. 5.

International Monetary Fund (2013), "Iceland Staff Report for the 2013 Article IV Consultation and Third Post-Program Monitoring Discussion," 16 July.

Jonung, Lars, Jaakko Kiander, and Pentti Vartia (2009), The Great Financial Crisis in Finland and Sweden: The Nordic Experience of Financial Liberalization, Edward Elgar.

Jónsson, Edvarð T. (1994), Hlutskipti Fareyja (The Fate of the Faroe Islands), Mál og menning. In Icelandic.

Laeven, Luc, and Fabián Valencia (2012), "Systemic Banking Crises Data Base: An Update,” IMF Working Paper WP/12/163.

Matthíasson, Thórólfur (2008), "Spinning out of control, Iceland in crisis,” Nordic Journal of Political Economy, Vol. 34, Article 3, pp. 1-19. 
National Audit Office (2013), Einkavaðing helstu ríkisfyrirtakja árin 1998-2003

(Privatization of main state enterprises 1998-2003), December. In Icelandic.

Níelsson, Ulf, and Bjarni K. Torfason (2012), "Iceland's Economic Eruption and Meltdown," Scandinavian Economic History Review, Vol. 60, No. 1, pp. 3-30.

O’Toole, Fintan (2009), Ship of Fools: How Stupidity and Corruption Killed the Celtic Tiger, Faber and Faber Ltd.

Ólafsson, Stefán, and Arnaldur Sölvi Kristjánsson (2013), "Inequality in Boom and Bust: A Tale from Iceland's Bubble Economy," in Janet Gomick and Markus Jäntti (eds.), Income Inequality: Economic Disparities and the Middle Class in Affluent Countries, Stanford University Press, pp. 416-438.

Paldam, Martin (2000), "Social Capital: One or Many? Definition and Measurement,“ Journal of Economic Surveys, Vol. 14, No. 5, December, pp. 629-653.

Polishchuk, Leonid, and Timur Natkhov (2012), "Institutions and the Allocation of Talent," Higher School of Economics Research Paper No. WP BRP 15/EC/2012.

Special Investigation Commission (2010), "Report of the Special Investigation Commission (SIC)," report delivered to Parliament, 12 April.

Stiglitz, Joseph E. (2010), Freefall: America, Free Markets, and the Sinking of the World Economy, W.W. Norton.

Wade, Robert H. (2009), "Iceland as Icarus,“ Challenge, Vol. 52, No. 3, May-June, pp. 5-33.

Wade, Robert H., and Silla Sigurgeirsdóttir (2012), “Iceland's Rise, Fall, Stabilisation and Beyond,“ Cambridge Journal of Economics, Vol. 36, No. 1, pp. 127-144.

Wenar, Leif (2008), "Property Rights and the Resource Curse," Philosophy and Public Affairs, Vol. 36, No. 1, Winter, 1-32.

World Bank (2006), Where Is the Wealth of Nations? Measuring Capital for the 21st Century, Washington, D.C. 